Article

\title{
Antioxidant Activity, Total Phenolic Content, Individual Phenolics and Physicochemical Parameters Suitability for Romanian Honey Authentication
}

\author{
Daniela Pauliuc, Florina Dranca ${ }^{\mathbb{D}}$ and Mircea Oroian * \\ Faculty of Food Engineering, Stefan cel Mare University of Suceava, 720225 Suceava, Romania; \\ daniela_pauliuc@yahoo.com (D.P.); florina.dranca@usm.ro (F.D.) \\ * Correspondence: m.oroian@fia.usv.ro; Tel.: +40-744-524-872
}

Received: 4 February 2020; Accepted: 4 March 2020; Published: 8 March 2020

\begin{abstract}
The present study aimed to evaluate the physicochemical characteristics of honey (raspberry, mint, rape, sunflower, thyme and polyfloral) produced in Romania. The honey samples were from the 2017 to 2018 harvest and were subjected to melissopalynological analysis, alongside the determination of the following physicochemical parameters: moisture content, $\mathrm{pH}$, free acidity, electrical conductivity (EC), hydroxymethylfurfural (HMF) content, color, total polyphenols content (TPC), flavonoids content (FC), DPPH radical scavenging activity, phenolic acids, flavonols, sugars and organic acids in order to evaluate the usefulness of this parameters for the classification of honey according to botanical origin. The results of the melissopalynological analysis revealed that five types of honey samples had a percentage of pollen grains above the minimum of $45 \%$, which was required in order to classify the samples as monofloral honey. The total polyphenols content reached the maximum value in the case of dark honey such as mint honey, followed by raspberry, thyme and polifloral honey. Fructose, glucose, maltose, sucrose, turanose, trehalose, melesitose, and raffinose were identified and quantified in all samples. Gluconic acid was the main organic acid in the composition of all honey samples. Principal component analysis (PCA) confirmed the possibility of the botanical authentication of honey based on these physicochemical parameters.
\end{abstract}

Keywords: honey; authentication; physicochemical parameters; PCA

\section{Introduction}

Honey is used both as medicine and a food source [1] and it is defined, according to Codex Alimentarius and EU Directive 110/2001 [2,3], as a sweet natural substance produced by bees (Apis melifera) from nectar or from the secretions of some plants, which is collected by bees and transformed by combining specific substances [4]. Honey is a complex food product, which is derived from nature and is the only natural sweetener that humans can use without processing [5], and therefore is very important economically [6].

Honey has a very complex chemical composition because it contains about $80 \%$ sugars, of which an important part is represented by glucose and fructose, $15-17 \%$ water, $0.1-0.4 \%$ protein and other compounds that are quantified as ash $0.2 \%[7,8]$. In addition, honey also contains, in small quantities, about 200 other constituents, which include amino acids, phenolic compounds, organic acids, vitamins, minerals, and enzymes [9]. This multitude of minor components can be added by bees or comes directly from nectar due to the ripening process [10,11].

The chemical composition depends on the source of honey, which refers to the botanical and geographical origin, as well as the environmental conditions [12]. Monofloral honey is increasingly required on the market and it is necessary to be able to determine some parameters regarding the 
authentication of the botanical and geographical origin. Monofloral honey is more expensive than polyfloral honey; honey labeled as having a certain floral origin must come entirely or largely from the specific floral source and exhibit the organoleptic, physicochemical and microscopic characteristics of the honey source, as provided in international food standards $[2,11]$.

Considering that bees feed on various plants, pure monofloral honey is generally very rare. The identification of the origin of honey and the proof of its authenticity has become an important problem with the globalization of the honey market, involving about 150 countries [13]. The interest in identifying the floral origin of honey has increased in recent years due to the high preference of consumers for certain types of honey. Consumer preferences often vary depending on different sensory perceptions and medicinal properties. Thus, numerous research has been published to date, which aimed to develop reliable methods for indicating the floral origin of honey [14].

Pollen analysis can be successfully used for the identification of the floral origin of honey. Therefore, melissopalinology should usually be supplemented by physicochemical and organoleptic analysis. Thus, to classify honey by botanical origin, a global interpretation of all results is required [15]. The melissopalynological analysis consists of counting the pollen grains and classify the honey according to its principal pollen grain percentage, for some honey such as sunflower, raspberry, rape and mint the principal pollen must reach at least $45 \%$ of the total pollen grains [16] while for thyme honey the Thymus spp. pollen grains must be at least $18 \%$ of the total pollen grains [17].

Therefore, new analytical methodologies were used to determine the botanical origin; these include the chromatographic, spectroscopic, e-tongue and molecular biological methods $[18,19]$. Physicochemical parameters (color, moisture, acidity) can vary widely in different types of honey and this contributes, to a certain extent, to their organoleptic characteristics. This is the reason why chromatographic techniques are more eloquent in the classification of honey and special attention should be paid to identifying certain specific minor components [20]. In addition to the classical techniques used to authenticate honey, the use of DNA-based methods for pollen identification has also spread. DNA-based identification has the potential to reduce processing time and increase the level of discriminated species [21]. Soares et al. [22] reported that they extracted the DNA markers and the yield and purity of the extracts were evaluated by UV spectrophotometry; this method was validated successfully with honey of known origins and applied to the entomological authentication of 20 commercial samples from different European countries.

Spectroscopic techniques, such as Fourier transform infrared spectroscopy (FTIR) and Raman spectroscopy, are alternative methods for authenticating honey and these techniques are reliable, practical and not time-consuming. FTIR spectroscopy is sensitive to the chemical composition of the sample, and when coupled with multivariate statistical analysis, it provides accurate results in determining the botanical origin of honey [9]. Svecnjak et al. [23] used FTIR-ATR spectroscopy to confirm the botanical origin of collected honey samples from beekeepers from different Croatian regions. Rheology and electrical tongue are also part of the alternative methods of authentication of honey. The voltammetry technique implies a high sensitivity and the electronic tongue can be regarded as a reference system in honey authentication [24]. Sousa et al. [25] reached a 100\% correct classification of chestnut (Castanea spp.), lavender (Lavandula spp.) and raspberry honey (Rubus spp.) with a potentiometric electronic tongue. The exact classification was obtained after honey samples were separated according to their color and then the authentication of each type of honey was done on their botanical origin.

NMR is a fingerprint technique that is used to obtain information about the structure of components [26]. Spiteri et al. [27] analyzed 816 honey samples from 60 different botanical origins by the NMR technique and observed specific profiles for the botanical sources of origin.

In this study, melissopalynological analysis and analysis of physicochemical parameters (moisture content, $\mathrm{pH}$, free acidity, electrical conductivity, hydroxymethylfurfural content, color, total polyphenols content, flavonoids content, DPPH radical scavenging activity, phenolic acids, flavonols, sugar 
composition, organic acids compositions) was performed to authenticate the botanical origin of sunflower, raspberry, thyme, mint, rape and polyfloral honey from Romania.

\section{Materials and Methods}

\subsection{Honey Samples}

Forty-five honey samples from the flowering season of 2017 to 2018 were purchased from beekeepers or apicultural associations from different regions in Romania.

Honey samples were kept away from sunlight at room temperature until the analysis. Thyme (Thymus spp.), rape (Brassica spp.), mint (Mentha piperita), raspberry (Rubus idaeus), and sunflower (Helianthus spp.) honey were of interest for this research.

\subsection{Melissopalynological Analysis}

Melissopalynological analysis was carried out according to Louveaux and Vorwohl [28]. The pollen was examined under a microscope using $\times 40$ magnification on a Motic microscope (Motic, Xiamen, China). For achieving the botanical origin at least 800 pollen grains were counted.

\subsection{Physicochemical Analysis}

\subsubsection{Moisture Content, $\mathrm{pH}$, Free Acidity, HMF Content and Electrical Conductivity}

Moisture content, free acidity, $\mathrm{pH}, \mathrm{HMF}$ content and electrical conductivity were determined according to the methods of the International Honey Commission $[8,29]$.

\subsubsection{Color}

Honey color analysis was performed using the Pfund scale (Pfund HI, Hanna Instruments, USA) and CIEL ${ }^{*}{ }^{*} b^{*}$ coordinates (portable chromameter CR-400, Konica Minolta, Tokyo, Japan), respectively.

\subsubsection{Determination of Total Phenolic Content}

The method proposed by Biesaga et al. [30] was used to determine the total phenolic content (TPC) and sample preparation was made, as follows: $1 \mathrm{~g}$ of honey sample was extracted with $5 \mathrm{~mL}$ of $40 \%$ methanol/acidified water $(v / v, \mathrm{pH}=2, \mathrm{HCl})$. Then, the samples were stirred for 15 min with a magnetic stirrer. From the extract, $0.2 \mathrm{~mL}$ was mixed with $2 \mathrm{~mL}$ of Folin-Ciocalteu reagent 1:10 and $1.8 \mathrm{~mL} \mathrm{Na}_{2} \mathrm{CO}_{3} 7.5 \%(w / v)$. The samples were kept in the dark for $20 \mathrm{~min}$ and the absorbance was measured at $750 \mathrm{~nm}$ using a UV-NIR spectrometer HR4000CG-UV-NIR (Ocean Optics, St. Petersburg, FL, USA). Gallic acid solutions with concentrations ranging from $0-400 \mathrm{mg} \cdot \mathrm{L}^{-1}$ were used to obtain the calibration curve.

\subsubsection{Determination of Flavonoids}

From the extract prepared as presented in Section 2.3.3, $5 \mathrm{~mL}$ were mixed with $300 \mu \mathrm{L}$ of $\mathrm{NaNO}_{2}$ $5 \%(w / v)$ and $300 \mu \mathrm{L}$ of $\mathrm{AlCl}_{3} 10 \%(w / v)$ [30]. After $5 \mathrm{~min}$ in the dark, the samples were mixed with 2 $\mathrm{mL}$ of $\mathrm{NaOH} 1 \mathrm{~N}$. The samples were kept for 6 more minutes in the dark and then the absorbance of each sample was read at $510 \mathrm{~nm}$ with a HR4000CG-UV-NIR spectrometer. Quercetin solutions with concentrations ranging from $0-10 \mathrm{mg} \cdot \mathrm{L}^{-1}$ were used to obtain the calibration curve.

\subsubsection{DPPH Assay}

The determination of 1,1-diphenyl-2-picrylhydrazyl (DPPH) radical scavenging activity required the following sample preparation: $1 \mathrm{~g}$ of honey was dissolved in $5 \mathrm{~mL}$ of methanol $40 \% \mathrm{v} / \mathrm{v}$, with acidified water) and stirred for $15 \mathrm{~min}$ with a magnetic stirrer [31]. Then, $35 \mu \mathrm{L}$ of honey solution was mixed with $250 \mu \mathrm{L}$ of DPPH. The absorbance was measured at $515 \mathrm{~nm}$ using a QE65000 spectrometer 
(Ocean Optics, St. Petersburg, FL, USA). The results were expressed as \% DPPH using the formula in Equation (1):

$$
\% \mathrm{DPPH}=\left(A_{0}-\frac{A_{1}}{A_{0}}\right) \times 100,
$$

where $A_{0}$ is the DPPH absorbance, $A_{1}$ is the sample absorbance.

\subsubsection{Determination of Sugars Composition}

Sugars composition was determined according to the IHC (International Honey Commission) methods $[8,29]$. The samples were filtered through $0.45 \mu \mathrm{m}$ PTFE membrane filters prior to the injection in the HPLC instrument (Schimadzu, Kyoto, Japan) equipped with a LC-20 AD liquid chromatograph, SIL-20A auto sampler, CTO-20AC column oven, and RID-10A refractive index detector. The separation was performed on a Phenomenex Luna ${ }^{\circledR}$ Omega 3 m SUGAR $100 \AA ̊$ APLC Column $150 \times 4.6$ mm. Peaks were identified based on their retention times and the determination of sugar content was made according to the external standard method on peak areas or peak heights. The mobile phase was acetonitrile:water $(80: 20, v / v)$, with a flow rate of $1.3 \mathrm{~mL} \cdot \mathrm{min}^{-1}$; column and detector temperature was $30{ }^{\circ} \mathrm{C}$ and the sample volume injection was $10 \mu \mathrm{L}$. Standard solutions of fructose, glucose, maltose, sucrose, turanose, trehalose, melesitose, and raffinose were individually injected to calculate the sugar content of each honey sample by using peak areas based on the retention time.

\subsubsection{Determination of Polyphenols Composition}

Honey solutions were prepared following the steps presented in Section 2.3.3 [30]. The samples were filtered through $0.45 \mu \mathrm{m}$ PTFE membrane filters and then injected (with a volume of $10 \mu \mathrm{L}$ ) into the HPLC instrument (Schimadzu, Kyoto, Japan) for analysis using an SPD-M-20A diode array detector. The separation was carried out on a Phenomenex Kinetex $2.6 \mu \mathrm{m}$ Biphenyl 100 A HPLC Column $150 \times 4.6 \mathrm{~mm}$ thermostated at $25^{\circ} \mathrm{C}$. Elution was carried out with a solvent system consisting of $0.1 \%$ acetic acid in water (solvent A) and acetonitrile (solvent B) as previously described by Palacios et al. [32] with modifications. The solvent flow rate was of $1 \mathrm{~mL} \cdot \mathrm{min}^{-1}$. The determined phenolic compounds were gallic acid, vanillic acid, protocatechuic acid and $p$-hydroxibenzoic acid at $280 \mathrm{~nm}$, and chlorogenic acid, $p$-coumaric acid, caffeic acid, rosmarinic acid, myricetin, quercetin, luteolin and kaempherol at $320 \mathrm{~nm}$. The obtained standard calibration curves showed high degrees of linearity $\left(R^{2}>0.99\right)$. Data collection and subsequent processing were performed using the LC solution software version 1.21 (Shimadzu, Kyoto, Japan).

\subsubsection{Determination of Organic Acids Composition}

The method used to determine the organic acids involved a sample preparation of $0.5 \mathrm{~g}$ of honey mixed with $2.5 \mathrm{~mL}$ of $4 \%$ metaphosphoric acid $(w / v)$, then the samples were vortexed. After, the samples were centrifuged for $5 \mathrm{~min}$ at $3500 \mathrm{rpm}$ using a Z216-MK refrigerated centrifuge (Hermle Labortechnik, Wemingen, Germany) [33]. The sample was injected in the HPLC instrument (Schimadzu, Kyoto, Japan) with a diode array detector. The separation was carried out on a Phenomenex Kinetex ${ }^{\circledR} 5 \mu \mathrm{m}$ C18 $100 \AA$ HPLC Column $250 \times 4.6 \mathrm{~mm}$. The mobile phase used was a mixture of $0.5 \%$ metaphosphoric acid and acetonitrile $(50 / 50, v / v)$ at a flow rate of $0.8 \mathrm{~mL} \cdot \mathrm{min}^{-1}$. The volume of injection was $10 \mu \mathrm{L}$. The organic acids identification and quantification were carried out at $210 \mathrm{~nm}$. The organic acids that were determined were acetic acid, lactic acid, propionic acid, butyric acid, and gluconic acid. The concentration of organic acids was expressed as $\mathrm{mg} / \mathrm{L}$.

\subsection{Statistical Analysis}

The analysis of variance (ANOVA) (LSD (least significant difference) test and $\alpha=0.05$ were applied) and principal component analysis (PCA) were used for achieving the suitability of the analyzed parameters for the botanical authentication of honey. ANOVA was carried out using Statgraphics 
Centurion XVIII software-trial version (Manugistics Corp., Rockville, MD, USA), while PCA was carried out using Unscrambler $X$ version 10.1 (Camo, Norway), respectively.

\section{Results}

\subsection{Melissopalynological Analysis}

Melissopalynological analysis is considered a traditional approach for the determination of the botanical origin of honey, and is a method of analysis that involves microscopic examination of pollen grains in order to identify the plants that were visited by bees during honey production [34]. Pollen analysis is a method developed and proposed by the International Bee Botanical Commission (IBBC) in 1970, which was revised in 1978 [28]. A honey sample can be classified as monofloral honey when more than $45 \%$ of the pollen grains belong to a single plant species for rape, raspberry, mint and sunflower [16], while thyme honey must be at least $18 \%$ total pollen grains [17]; this type of honey is the most preferred by consumers for its specific aroma, taste and biological properties $[18,19]$. The melissopalynological analysis is presented in Table 1 . The raspberry honey had the principal pollen Rubus idaeus (49.1-82.3\%), rape honey had the principal pollen Brassica spp. (50.1-71.1\%), sunflower has the principal pollen Helianthus spp. (46.5-92.1\%) and thyme had the principal pollen Thymus spp. (22-45\%), respectively.

Table 1. Pollen types in honey samples.

\begin{tabular}{cc}
\hline Honey Type & Principal Pollen Type (min.\%-max.\%) \\
\hline Raspberry & Rubus idaeus $(49.1-82.3 \%)$ \\
Rape & Brassica spp. $(50.1-71.1 \%)$ \\
Sunflower & Helianthus spp. $(46.5-92.1 \%)$ \\
Mint & Mentha spp. $(46.5-65.1 \%)$ \\
Thyme & Thymus spp. $(22-45 \%)$ \\
\hline
\end{tabular}

Based on pollen analysis, the samples were classified according to the botanical origin as raspberry (6 samples), rape (10 samples), sunflower (9 samples), thyme (4 samples), mint (10 samples) and polyfloral honey (6 samples). Of the monofloral honey samples, the highest percentage of pollen grains was found in rape and sunflower honey.

\subsection{Moisture Content}

The moisture content of honey is dependent on factors such as the relative humidity in the region where honey comes from and the processing and storage conditions [11]. The Codex Alimentarius standard established that the moisture content of honey must be below $20 \%$ [2]. Honey samples that do not meet this criterion could become unstable during storage and thus be susceptible to deterioration by fermentation caused by yeast and bacteria naturally found in honey [35]. The moisture content of the analyzed samples ranged between an average value of $17.36 \%$ in thyme samples and a maximum average value of $19.60 \%$ in the polyfloral honey samples, as shown in Table 1 . The botanical origin of honey did not influence the variation of the moisture content $(p>0.05)$, while the year of honey production had some influence $(p<0.05)$ on this parameter. All honey samples had moisture contents in the limits established by legislation. The mint and thyme honey samples had values between $17.36 \%$ (thyme honey) and $17.77 \%$ (mint honey), while Boussaid et al. [36] reported for mint honey the value of $19.8 \%$ and for thyme honey, $18.16 \%$. The results of this analysis were in accordance with the values reported by Karabagias et al. [17] who determined in honey samples a moisture content that ranged from $10.74 \%$ (Symi honey sample) to $20.94 \%$ (Lakonia honey sample). Mărghitaș et al. [37] reported a variation in the moisture content for the Romanian honey between $16.6 \%$ and $20 \%$, while Küçük et al. [38] reported values of moisture content from 19\% to 19.7\% for Anatolian honey. Escuredo et al. [39] determined a moisture content between $15.5 \%$ and $19.8 \%$ for honey samples from Spain. 
3.3. $p H$

Honey has a pH that usually varies between 3.5 and 5.5 and is dependent on the compositions of organic acids, which are chemical components that give the aroma of honey and at the same time protect it against microbiological damage. Therefore, the $\mathrm{pH}$ can be considered an indicator of potential microbial growth, as a value of 7.2 to 7.4 is optimal for the development of most microorganisms. The average $\mathrm{pH}$ values of the honey samples ranged from 3.91 in the case of thyme honey to a maximum of 4.22 in the case of rape honey (Table 2).

Differences in this parameter were determined by the botanical origin of honey $(p<0.05)$, but not by year $(p>0.05)$. Romanian mint and thyme honey samples had $\mathrm{pH}$ values similar to Tunisian mint and thyme honey [36]. In Tunisian mint honey samples, the $\mathrm{pH}$ value was 4.11 [36], while in Romanian mint honey, it was 4.20. For thyme honey, the $\mathrm{pH}$ value was 3.87 (Tunisian honey) and 3.91 (Romanian honey).

Therefore, a pH between 3.2 and 4.5 was considered acceptable for honey samples [11] and the $\mathrm{pH}$ values determined for the studied samples were within this range. The $\mathrm{pH}$ of honey is of particular importance during the extraction and storage of honey because of its influence on the texture, stability and storage time [5]. The average $\mathrm{pH}$ values of honey samples from Vojvodina (Serbia) ranged between 3.88 (sunflower honey) and 3.99 (acacia honey) [35]. 
Table 2. Physicochemical properties for different types of honey (raspberry, mint, rape, thyme, polyfloral and sunflower). Mean values and standard deviation in brackets.

\begin{tabular}{|c|c|c|c|c|c|c|c|c|c|c|}
\hline \multirow{2}{*}{ Parameter } & \multicolumn{6}{|c|}{ Origin } & \multirow{2}{*}{ F Value } & \multicolumn{2}{|c|}{ Year } & \multirow{2}{*}{ F Value } \\
\hline & Mint & Polyfloral & Rape & Raspberry & Sunflower & Thyme & & 2017 & 2018 & \\
\hline $\mathrm{L}^{*}$ & $35.3(6.24)^{b c}$ & $46.1(3.67)^{a}$ & $41.4(3.48)^{\mathrm{a}}$ & $34.4(3.36)^{c}$ & $41.05(6.93)^{\mathrm{a}}$ & $43.2(6.31)^{\mathrm{ab}}$ & $5.05^{* * *}$ & $40.5(5.58)^{\mathrm{a}}$ & $39.3(7.03)^{\mathrm{a}}$ & $1.67^{\mathrm{ns}}$ \\
\hline$h_{a b}$ & $65.6(9.38)^{\mathrm{d}}$ & $84.7(10)^{b}$ & $96.6(6.03)^{a}$ & $73.4(8.43)^{\mathrm{c}}$ & $83.4(3.17)^{\mathrm{b}}$ & $81.8(4.76)^{b c}$ & $20.30^{* * *}$ & $79.6(12.56)^{\mathrm{a}}$ & $82.2(13.48)^{a}$ & $1.56^{\mathrm{ns}}$ \\
\hline$c_{a b}$ & $19.7(3.42)^{\mathrm{c}}$ & $26.2(5.37)^{a b}$ & $19.2(6.66)^{c}$ & $23.8(1.78)^{b c}$ & $27.2(5.81)^{\mathrm{a}}$ & $29.8(4.48)^{a}$ & $7.71^{* * *}$ & $26.3(5.43)^{\mathrm{a}}$ & $21.1(5.72)^{\mathrm{b}}$ & $24.85^{* * *}$ \\
\hline Pfund (mm Pfund) & $74.3(14.54)^{\mathrm{a}}$ & $40.9(20.41)^{\mathrm{cd}}$ & $29.4(11.16)^{d}$ & $61.4(14.35)$ ab & $37.6(10.23)^{c d}$ & $50.1(12.29) \mathrm{bc}$ & $13.28^{* * *}$ & $49.4(21.19)^{\mathrm{a}}$ & $48.1(21.96)^{a}$ & $0.01^{\mathrm{ns}}$ \\
\hline $\mathrm{pH}$ & $4.20(0.25)^{\mathrm{a}}$ & $4.09(0.24)^{\text {ab }}$ & $4.22(0.08)^{\mathrm{a}}$ & $4.16(0.12)^{\mathrm{a}}$ & $3.94(0.25)^{b}$ & $3.91(0.19)^{\mathrm{ab}}$ & $2.51 *$ & $4.08(0.25)^{\mathrm{a}}$ & $4.1(0.21)^{\mathrm{a}}$ & $0.67^{\mathrm{ns}}$ \\
\hline Free acidity $\left(\mathrm{meg} \cdot \mathrm{kg}^{-1}\right)$ & $26.9(8.89)^{a}$ & $23.9(12.54)^{\text {ab }}$ & $16(4.43)^{\mathrm{b}}$ & $27.3(7.71)^{\mathrm{a}}$ & $31.6(12.20)^{a}$ & $22.5(8.16)^{\mathrm{ab}}$ & $3.07 * *$ & $22.01(8.69)^{a}$ & $26.8(11.12)^{a}$ & $2.28^{\mathrm{ns}}$ \\
\hline $\mathrm{EC}\left(\mu \mathrm{S} \cdot \mathrm{cm}^{-1}\right)$ & $474(92.76)^{a}$ & $354(242.77) a b c$ & $162(38.26)^{d}$ & $446(68.57)^{\mathrm{ab}}$ & $362(55.03) \mathrm{bc}$ & $244(54.13)^{\mathrm{cd}}$ & $10.71^{* * *}$ & $310(154.86)^{a}$ & $367(151.89)^{a}$ & $2.28^{\mathrm{ns}}$ \\
\hline Moisture (\%) & $17.7(1.10)^{b}$ & $19.6(1.65)^{\mathrm{a}}$ & $18.4(0.86)^{\mathrm{ab}}$ & $18.3(1.05)^{\mathrm{ab}}$ & $18.4(1.48)^{\mathrm{ab}}$ & $17.3(1.95)^{b}$ & $1.71^{\mathrm{ns}}$ & $17.9(1.01)^{\mathrm{a}}$ & $18.6(1.56)^{\mathrm{a}}$ & $3.76^{*}$ \\
\hline $\mathrm{HMF}\left(\mathrm{mg} \cdot \mathrm{kg}^{-1}\right)$ & $29.2(23.22)^{\mathrm{a}}$ & $10(8.84)^{\mathrm{b}}$ & $13.3(14.10)^{b}$ & $18.7(16.33)^{\mathrm{b}}$ & $8.26(4.49)^{b}$ & $30.8(20.96)^{a}$ & $6.24 * * *$ & $28.4(26.31)^{\mathrm{a}}$ & $20.2(26.26)^{\mathrm{a}}$ & $0.72^{\mathrm{ns}}$ \\
\hline TPC (mg GAE $\left.100 \mathrm{~g}^{-1}\right)$ & $23.7(4.37)^{\mathrm{a}}$ & $20.3(7.67)^{\mathrm{a}}$ & $19.9(4.83)^{\mathrm{a}}$ & $19.9(4.83)^{\mathrm{a}}$ & $21.1(7.18)^{\mathrm{a}}$ & $18.9(3.82)^{\mathrm{a}}$ & $0.35^{\mathrm{ns}}$ & $21.4(5.83)^{\mathrm{a}}$ & $20.5(5.98)^{\mathrm{a}}$ & $1.15^{\mathrm{ns}}$ \\
\hline $\mathrm{FC}\left(\mathrm{mg} \mathrm{QE} \cdot 100 \mathrm{~g}^{-1}\right)$ & $25.7(10.55)^{\mathrm{b}}$ & $24.1(5.76)^{b}$ & $20.2(12.21)^{b}$ & $33.5(6.62)^{\text {a }}$ & $22.8(8.73)^{\mathrm{b}}$ & $17.4(9.33)^{b}$ & $2.29 \mathrm{~ns}$ & $21.1(10.42)^{a}$ & $26.3(9.46)^{a}$ & $4.26^{*}$ \\
\hline DPPH $(\%)$ & $74.03(5.84)$ ab & $70.7(15.90)$ ab & $55.4(6.88)^{\mathrm{c}}$ & $79.05(13.51)^{a}$ & $68.03(8.01)^{\mathrm{b}}$ & $67.3(9.82)^{a b}$ & $5.24 * * *$ & $67.3(13.12)^{a}$ & $69.1(11.38)^{a}$ & $0.68^{\mathrm{ns}}$ \\
\hline
\end{tabular}

ns not significant $(p>0.05) * p<0.05, * * p<0.01, * * * p<0.001,{ }^{a-d}$ different letters in the same row indicate significant differences between samples $(p<0.001)$ according to the LSD test with $\alpha=0.05$. Pfund-color in Pfund scale, EC—electrical conductivity, HMF-5-hydroxymethylfurfural, TPC—total phenolic content, FC—flavonoids content, DPPH—radical scavenging activity. 


\subsection{Free Acidity}

The free acidity of honey is determined by the presence of organic acids and other compounds such as esters, lactones and inorganic ions found in its composition [11]. Contribution to this parameter also presents the composition of protein, phenolic acids and vitamin $\mathrm{C}$, which are chemical components that act as $\mathrm{H}^{+}$donors [40]. Determining the acidity helps to appreciate the freshness of the honey. As the composition of honey deteriorates, an increase of free acidity occurs as a result of the fermentation of sugars into organic acids. According to the EU legislation [41], for this parameter a maximum of 50 milliequivalents of acid per $1000 \mathrm{~g}$ is allowed [2]. In our study, the highest acidity was determined in sunflower $\left(31.63 \mathrm{meq} \cdot \mathrm{kg}^{-1}\right)$ honey and the lowest $\left(16.01 \mathrm{meq} \cdot \mathrm{kg}^{-1}\right)$ in rape honey (Table 2$)$. The botanical origin of honey had a significant influence on this parameter $(p<0.01)$, while the year of production determined no significant variation between samples $(p>0.05)$. Lazarević et al. [42] observed similar results, they determined the highest free acidity $(27.2 \mathrm{meq} / \mathrm{kg})$ in sunflower honey and the lowest values of the parameter $\left(11.6 \mathrm{meq} \cdot \mathrm{kg}^{-1}\right)$ in acacia honey. Significant differences in the function of the botanical origin of honey were also reported for the free acidity of acacia and hay honey [43]. Oroian and Ropciuc [44] reported that free acidity varied between $6.63 \mathrm{meq} \cdot \mathrm{kg}^{-1}$ in tilia honey, $13.02 \mathrm{meq} \cdot \mathrm{kg}^{-1}$ in sunflower honey and reached the maximum value in the case of polifloral honey $\left(20.83 \mathrm{meq} \cdot \mathrm{kg}^{-1}\right)$.

\subsection{HMF Content}

The HMF content is a chemical parameter that can be used to study the degree of freshness of honey and consequently its degree of deterioration. The causes of honey deterioration could be due to strong or prolonged thermal treatment and inadequate storage conditions [45]. As seen in Table 2, honey samples had an HMF content between a minimum of $8.26 \mathrm{mg} \mathrm{HMF} \cdot \mathrm{kg}^{-1}$ (sunflower honey) and a maximum of $50.8 \mathrm{mg}$ HMF. $\mathrm{kg}^{-1}$ (thyme honey). Botanical origin had a significant influence $(p<0.001)$ on this parameter. For some of the samples of mint (two samples) and thyme honey (one sample) that were analyzed, the HMF content was above the maximum concentration $\left(40 \mathrm{mg} \cdot \mathrm{kg}^{-1}\right)$ allowed by European legislation [41]. In the case of these samples, it is possible that there was an overheating during processing and/or storage, which might have influenced the HMF content in honey.

Rodríguez et al. [46] observed that the avocado honey had a maximum level of HMF of $27.1 \mathrm{mg} \cdot \mathrm{kg}^{-1}$. Another study, focused on the quality of honey from Rio Grande do Sul State (Brazil), reported values of $0.47-22.72 \mathrm{mg} \mathrm{HMF} \cdot \mathrm{kg}^{-1}$ of honey, which met the quality requirements established by both Brazilian legislation (upper limit of $60 \mathrm{mg} \mathrm{HMF} \cdot \mathrm{kg}^{-1}$ ) and international standards (Codex, 2001-maximum of $\left.40 \mathrm{mg} \mathrm{HMF} \cdot \mathrm{kg}^{-1}\right)$ [47].

\subsection{Color}

The appearance of honey is very important for consumers. The color of honey is a sensory parameter that varies between different types of honey and is dependent on chemical parameters such as mineral content and polyphenols content [48]. Regarding the mineral composition, it was argued that amber and dark honey have a higher content of certain minerals $(\mathrm{Na}, \mathrm{K}, \mathrm{Ca}, \mathrm{Mg}, \mathrm{Fe}, \mathrm{Cu}, \mathrm{Zn}$, $\mathrm{Al}, \mathrm{Ni}, \mathrm{Cd}$ and $\mathrm{Mn}$ ) by comparison to light-colored honey [49]. Furthermore, transition metals seem to influence the color of honey through the formation of complexes with some organic compounds. The color of honey can be also affected by both storage and thermal processing which was linked to the formation of Maillard reaction products [11].

As previously mentioned, color is a parameter that is dependent on the botanical origin of honey, as shown by the values in Table 2. The color values presented on the Pfund scale were used to classify honey by color. The color of the analyzed honey samples varied between white (rape honey), extra light amber (sunflower honey, thyme and polyfloral) and light amber (mint and raspberry honey). Manzanares et al. [50] analyzed 85 samples of honey from Tenerife, Spain and reported values between 24 and $150 \mathrm{~mm}$ Pfund. The color of honey samples was characterized by red and yellow shades (first quadrant of CIEL $a^{*} b^{*}$ color space), as $a^{*}$ and $b^{*}$ coordinates had positive values. The lightness values 
$\left(\mathrm{L}^{*}\right)$ of the six Tunisian honey samples analyzed by Boussaid et al. [36] ranged from 36.64 to 51.37, while in our honey samples it ranged from 34.4 to 46.1 .

\subsection{Electrical Conductivity}

Another physical parameter that serves as a means to authenticate honey, and particularly the monofloral types, is electrical conductivity. Electrical conductivity is a parameter included in the new international standards regarding the differentiation between honeydew and flower honey. The limits of this parameter that were specified by standards are 500 to $800 \mu \mathrm{S} \cdot \mathrm{cm}^{-1}$ for mixed honey and $<500 \mu \mathrm{S} \cdot \mathrm{cm}^{-1}$ in the case of pure floral honey with some exceptions [51]. Values greater than $800 \mu \mathrm{S} \cdot \mathrm{cm}^{-1}$ are specific to honeydew and therefore are not acceptable for floral honey, and can confirm an adulteration with inverted sugar [52-54]. In the work of Kaskoniene et al. [55] it was shown that floral honey has an electrical conductivity that was lower than that of honeydew, confirming that this parameter is a quality indicator that can be used as a means to distinguish honeydew from floral honey [56].

As the values in Table 2 show, the honey samples analyzed had an electrical conductivity of less than $500 \mu \mathrm{S} \cdot \mathrm{cm}^{-1}$, so they can be classified as pure floral honey. Mint honey had the highest electrical conductivity $\left(474.05 \mu \mathrm{S} \cdot \mathrm{cm}^{-1}\right)$ followed by raspberry honey $\left(446.16 \mu \mathrm{S} \cdot \mathrm{cm}^{-1}\right)$. Polyfloral and sunflower honey presented close values of electrical conductivity $\left(354.09 \mu \mathrm{S} \cdot \mathrm{cm}^{-1}\right.$ and $\left.362.27 \mu \mathrm{S} \cdot \mathrm{cm}^{-1}\right)$ and rape and thyme honey were characterized by the lowest values of electrical conductivity $\left(162.5 \mu \mathrm{S} \cdot \mathrm{cm}^{-1}\right.$ in rape honey and $244.28 \mu \mathrm{S} \cdot \mathrm{cm}^{-1}$ in thyme honey). Botanical origin had a significant influence $(p<0.001)$ on the variation of this parameter. Boussaid et al. [36] reported for Tunisian mint honey an electrical conductivity of $430 \mu \mathrm{S} \cdot \mathrm{cm}^{-1}$, which was similar to our results for mint honey. In the case of thyme honey, the value reported for Tunisian honey was higher than the electrical conductivity measured for the Romanian thyme honey. Oroian and Ropciuc [44] reported, in the case of sunflower honey, an electrical conductivity value of $346.1 \mu \mathrm{S} \cdot \mathrm{cm}^{-1}$ and $431.4 \mu \mathrm{S} \cdot \mathrm{cm}^{-1}$ for the polyfloral honey. Usually, monofloral rape honey has low electrical conductivity, 130 to $580 \mu \mathrm{S} \cdot \mathrm{cm}^{-1}$ [57] and 110-270 $\mu \mathrm{S} \cdot \mathrm{cm}^{-1}$ [58], which indicates that this type of honey has a lower mineral content [55]. By comparing these reported values to the values we have determined for the electrical conductivity of our rape honey samples, it can be concluded that the samples analyzed in this study were of pure rape honey.

Regarding the influence of other parameters on the electrical conductivity of honey, it was found that the variation of this parameter positively correlated with an increased ash and acid content [8]. The pollen collected by bees is a major source of minerals, and consequently, in the case of monofloral honey the electrical conductivity correlated with the pollen content [55] and may serve as a means to identify the botanical origin of honey [59]. This parameter was included in international standards to replace the ash content determination [2]. The electrical conductivity is a good criterion for identifying the botanical origin of honey and is also used for its routine control [60].

\subsection{Total Phenolic Content}

The functional properties of honey are related to the number of natural antioxidants from pollen collected by bees and other floral nectars [61]. The antioxidant effects of honey were attributed to the presence of phenolic acids, flavonoids, ascorbic acid, carotenoids, catalase, peroxidase, as well as Maillard reaction products in the composition of honey [62,63]. Table 2 presents the total phenolic content (TPC) of raspberry, mint, thyme, rape, sunflower and polyfloral honey samples. TPC varied between $18.91 \mathrm{mg} \mathrm{GAE} \cdot 100 \mathrm{~g}^{-1}$ (thyme honey) and $23.71 \mathrm{mg} \mathrm{GAE} \cdot 100 \mathrm{~g}^{-1}$ (mint honey); no significant differences were determined by botanical origin and year.

Chua et al. [64] reported in their study that the TPC of the analyzed honey samples ranged from 110.39 to $196.500 \mathrm{mg} \mathrm{GAE} \cdot 100 \mathrm{~g}^{-1}$. In their study on four types of honey, Marghitaş et al. [37] reported that sunflower honey had the highest value of total polyphenol content ( $\left.40 \mathrm{mg} \mathrm{GAE} \cdot 100 \mathrm{~g} \mathrm{~g}^{-1}\right)$, while acacia honey had values between 2 and $39 \mathrm{mg} \mathrm{GAE} \cdot 100 \mathrm{~g}^{-1}$. The total phenolic content of Indian honey was found in the range of $47 \mathrm{mg}$ GAE $\cdot 100 \mathrm{~g}^{-1}$ of honey to $98 \mathrm{mg}$ GAE/100 $\mathrm{g}$ of honey [51]. The TPC 
values determined for Romanian monofloral honey in our study were lower than those obtained by other authors when analyzing honey of different origin.

\subsection{Flavonoids Content}

The flavonoids of honey may originate from pollen, nectar or propolis [65]. In general, the main flavonoids found in honey are pinocembrin, apigenin, campferol, quercetin, pinobanksin, luteolin, galangin, hesperetin, and isorhamnetin [15]. Flavonoids have low molecular weight and are vital components of honey and its antioxidant properties [66]. Table 2 shows the values determined for flavonoids content by botanical origin and year of honey production. As in the case of total polyphenols, in this study the thyme honey samples had the lowest flavonoid content $(17.45 \mathrm{mg}$ QE.100 g $\left.{ }^{-1}\right)$. The highest flavonoid content was identified in raspberry honey (33.58 mg QE. $100 \mathrm{~g}^{-1}$ ) followed by mint honey ( $\left.25.73 \mathrm{mg} \mathrm{QE} \cdot 100 \mathrm{~g}^{-1}\right)$, polyfloral honey $\left(24.14 \mathrm{mg} \mathrm{QE} \cdot 100 \mathrm{~g}^{-1}\right)$, sunflower honey (22.86 mg QE.100 g $\left.\mathrm{g}^{-1}\right)$ and rape honey $\left(20.25 \mathrm{mg} \mathrm{QE} \cdot 100 \mathrm{~g}^{-1}\right)$. The flavonoids content was influenced by year $(p<0.05)$, but not by botanical origin $(p>0.05)$.

Mărghitaş et al. [37] reported that the total flavonoid content of honey samples ranged between 0.91-2.42 mg QE·100 g ${ }^{-1}$ in acacia honey, $4.70-6.98 \mathrm{mg}$ QE$\cdot 100 \mathrm{~g}^{-1}$ in tilia honey, and $11.53-15.33 \mathrm{mg}$ QE.100 $\mathrm{g}^{-1}$ in sunflower honey. Boussaid et al. [36] reported higher total flavonoids content in mint honey $\left(22.45 \mathrm{mg} \mathrm{QE} \cdot 100 \mathrm{~g}^{-1}\right)$, and lower in the case of rosemary $\left(16.24 \mathrm{mg}\right.$ QE$\left.\cdot 100 \mathrm{~g}^{-1}\right)$, thyme $(14.77 \mathrm{mg}$ QE.100 $\left.\mathrm{g}^{-1}\right)$, orange $\left(11.12 \mathrm{mg} \mathrm{QE} \cdot 100 \mathrm{~g}^{-1}\right)$, horehound (11.02 mg QE·100 g $\left.{ }^{-1}\right)$, and eucalyptus (9.58 mg QE.100 $\mathrm{g}^{-1}$ ) honey.

\subsection{DPPH Assay}

The DPPH assay was used as a means to determine the free radical-scavenging activity of the honey samples. In this study the highest DPPH radical scavenging activity (Table 2) was identified for raspberry honey $(79.05 \%)$ and mint honey $(74.03 \%)$, and the lowest for thyme $(63.77 \%)$ and rape honey (55.49\%). Lachman et al. [67] also determined a lower antioxidant activity from the DPPH assay for rape honey and higher for raspberry honey in a study on honey samples from the Czech Republic. Blasa et al. [68] and Salonen et al. [69] argued that light-colored honey possessed lower antioxidant activity by comparison to darker colored honey, an observation that seems to be accurate for our study, although the differences between the free radical scavenging activities of our honey samples were not as pronounced as in the case of the above-mentioned studies.

DPPH radical scavenging activity is a parameter that varied significantly $(p<0.001)$ depending on the botanical origin of the honey samples analyzed. By comparison to the antioxidant activities reported for honey samples from other geographical regions, which include studies by Ruiz-Navajas et al. [70] who reported values of 33.4-85.5\% for honey from Tabasco (Mexico) and Baltrusaityte et al. [71] who reported for honey from Lithuania values between $31.1 \%$ and $86.9 \%$, Romanian honey had overall higher antioxidant activities.

\subsection{Sugars Composition}

Honey contains simple carbohydrates, namely glucose and fructose known as monosaccharides, which represent $65-80 \%$ of the total soluble solids, as well as $25 \%$ of other oligosaccharides (disaccharides, trisaccharides, tetrasaccharides) [72]. Determination of disaccharide content (mainly maltose and sucrose) is a tool for characterizing honey; maltose content was used to classify Spanish honey and to differentiate Brazilian honey from different geographical regions [72].

In the analyzed honey samples (Table 3), the highest fructose content was identified in thyme honey $(36.77 \%)$ and the lowest in polyfloral honey (35.15\%). Rape honey had the highest glucose content $(31.78 \%)$ and polyfloral honey had the lowest content $(24.95 \%)$ of this monosaccharide. Glucose content was the only parameter that varied significantly $(p<0.01)$ depending on the botanical origin of the analyzed samples. Maltose (maximum value of $1.79 \%$ in polyfloral honey), trehalose (maximum value of $2.35 \%$ in rape honey) and melesitose (maximum value of $1.34 \%$ in thyme honey) were sugars 
that together with fructose and glucose were found in significant concentrations in the analyzed honey samples. Sucrose and rafinose had values between $0.07 \%$ (raspberry honey) and $0.73 \%$ (polyfloral honey), respectively $0.21 \%$ (rape honey) and $0.42 \%$ (polyfloral honey). Apart from individual sugars, for all 45 honey samples, the fructose/glucose ratio was also calculated. When the content of fructose is higher than that of glucose honey is fluid, thus, this ratio can be used to identify the crystallization state of honey [73,74]. Suarez et al. [75] reported that the fructose/glucose ratio might also impact the flavor of honey since fructose is sweeter than glucose. All honey samples examined were fluid, as the fructose/glucose ratio was greater than 1 (Table 2).

Some authors argued that the amount and ratio of specific carbohydrates, such as fructose, glucose and oligosaccharides can be used to identify whether honey is monofloral or polyfloral [76]. Kaskonien \& Venskutonis [55] considered that the use of carbohydrates as floral markers is not often preferred because of the difficulties encountered in identifying one or more sugars contained by honey. Cotte et al. [76] analyzed authentic monofloral honey samples and found differences in the carbohydrate composition based on botanical origin. Fir honey samples were high in trisaccharides, in particular raffinose $(2.1 \%)$, melesitose $(5.7 \%)$ and erlose $(2.1 \%)$. In contrast, in rape and sunflower honey these trisaccharides were absent, which serves as a way to distinguish them from other botanical varieties. Acacia honey has a high concentration of trisaccharides (1.9\%), with erlose being the predominant trisaccharide in this type of honey; lavender and tilia honey were characterized by lower concentrations of erlose (1.4 and $1.0 \%$ respectively) [76].

\subsection{Polyphenols Composition}

Polyphenols are powerful antioxidants that can reach more than $0.8 \%$ (by weight) in bee products [77]. Phenolic acids and flavonoids were extensively investigated in honey [78] and were used to evaluate its quality. The correlations between antioxidant activity and total concentration of phenols was confirmed for seven types of honey from Italy [79] and four honey types from Romania [37]. In another study on Portuguese honey, it was shown that polyphenols in honey were responsible for its antimicrobial effects [80]. Phenolic compounds can be used to classify honey according to its botanical origin [78]. The composition of honey in polyphenols was found to be mostly dependent on the botanical origin due to the fact that these compounds mostly originate from the nectar collected by bees; the nature and quantity of phenolic compounds can also vary with the season, climatic conditions and processing factors $[63,79]$.

In the studied samples, 12 polyphenols were analyzed, which were mostly found in all samples in different concentrations (Table 4). Gallic acid was found at a high concentration $\left(1.55 \mathrm{mg} \cdot 100 \mathrm{~g}^{-1}\right)$ in mint honey, while the lowest value was identified in thyme honey $\left(0.57 \mathrm{mg} \cdot 100 \mathrm{~g}^{-1}\right)$. The protocatechuic and 4-hydroxybenzoic acids were identified in higher concentrations in mint (2.04 $\mathrm{mg}$ protocatechuic acid $100 \mathrm{~g}^{-1}$ and $1.20 \mathrm{mg}$ 4-hydroxybenzoic acid $\left.\cdot 100 \mathrm{~g}^{-1}\right)$ and raspberry honey (2.57 $\mathrm{mg}$ protocatechuic acid $100 \mathrm{~g}^{-1}$ and $2.33 \mathrm{mg}$ 4-hydroxybenzoic acid $\left.\cdot 100 \mathrm{~g}^{-1}\right)$. Compared to other honey types, mint also had a high content of vanillic acid $\left(3.03 \mathrm{mg} \cdot 100 \mathrm{~g} \mathrm{~g}^{-1}\right)$ and chlorogenic acid $\left(1.48 \mathrm{mg} \cdot 100 \mathrm{~g}^{-1}\right)$. These two phenolic acids were also found in sunflower and thyme honey in large quantities. Caffeic acid predominated in polyfloral honey $\left(1.20 \mathrm{mg} \cdot 100 \mathrm{~g}^{-1}\right)$ and did not exceed the level of $0.38 \mathrm{mg} \cdot 100 \mathrm{~g}^{-1}$ in other honey samples. Thyme honey had the highest content of $p$-coumaric acid, while myricetin predominated in rape honey, although it was found in all types of honey. Rosmarinic acid was found only in raspberry honey at a very small concentration of $0.03 \mathrm{mg} \cdot 100 \mathrm{~g}^{-1}$, while kaempferol was determined only in polyfloral honey in a concentration of $0.38 \mathrm{mg} \cdot 100 \mathrm{~g}^{-1}$. Quercetin was quantified only in 3 types of honey: mint, polifloral and sunflower honey and luteolin was not determined in any sample.

Gasic et al. [81] observed that quercetin and eriodictiol can be used for sunflower honey authentication and we observed too that quercetin is presented in the sunflower honey analyzed. 


\subsection{Organic Acids Composition}

Organic acids are found in honey in small quantities $(<0.5 \%)$, but are important chemical components because of their significant contribution to the stability and preservation of the physicochemical and sensory properties of honey [11].

The total acid content increases due to the fermentation phenomena and aging that may occur during storage [82]. Some authors have suggested that organic acid profiles are useful for identifying the botanical and/or geographical origin of honey [83].

As shown in Table 5, the predominant acid in all the honey samples analyzed was gluconic acid. The maximum gluconic acid content was determined in raspberry honey $\left(4.83 \mathrm{~g} \cdot \mathrm{kg}^{-1}\right)$ and the lowest value in rape honey (3.59 $\left.\mathrm{g} \cdot \mathrm{kg}^{-1}\right)$. Brugnerotto et al. [84] also identified gluconic acid as the predominant acid in all the honey samples that they studied. Gluconic acid is predominant in both honeydew and floral honey and its concentration can be influenced by the botanical source and the pollen and nectar of the flowers collected by bees. In our study, the concentration of gluconic acid was not influenced by botanical origin or year of production $(p>0.05)$.

Romanian mint and thyme honey were also high in propionic acid $\left(2.67 \mathrm{~g} \cdot \mathrm{kg}^{-1}\right.$ and $\left.2.36 \mathrm{~g} \cdot \mathrm{kg}^{-1}\right)$. Honey samples had a succinic acid content that ranged from a minimum value of $0.05 \mathrm{~g} \cdot \mathrm{kg}^{-1}$ in raspberry honey to a maximum value of $0.13 \mathrm{~g} \cdot \mathrm{kg}^{-1}$ in mint honey. In the study conducted by Suarez-Luque et al. [85] on 50 honey samples from Galicia (Santiago de Compostela, Spain), the succinic acid content was much higher. Formic, acetic, lactic and butyric acid were determined in low concentrations in all honey samples. The content of honey samples in both propionic and acetic acids was strongly influenced $(p<0.001)$ by botanical origin.

The quantification of malonic and glycolic acids in floral honey was firstly reported in a study by Brugnerotto et al. [84] who determined concentrations of $82.2-134 \mathrm{mg}$ malonic acid $\cdot 100 \mathrm{~g}^{-1}$ and $27.8-43.7 \mathrm{mg}$ glycolic acid $100 \mathrm{~g}^{-1}$. Acetic, lactic, formic, and propionic acids were identified in lower concentrations, while fumaric and tartaric acids were not detected. In their study, citric and malic acid concentrations were of $48.2-506 \mathrm{mg} \cdot 100 \mathrm{~g}^{-1}$ and $19.9-132 \mathrm{mg} \cdot 100 \mathrm{~g}^{-1}$, respectively [84].

Suarez-Luque et al. [85] also observed variations in the composition of organic acids in honey that were attributed to its botanical origin. The concentration of citric, malic, succinic and fumaric acid was high in chestnut honey and low in eucalyptus honey. Polyfloral honey had a high content of maleic acid, while clover honey did not contain malic and succinic acids.

The concentration and content of organic acids, as well as ketones and benzene compounds such as 2-hydroxy-2-propanone, 2-phenylethanol, butanoic acid or benzyl alcohol, which were identified in fresh honey, increase with temperature and storage time [86].

\subsection{Principal Component Analysis (PCA)}

Principal component analysis (PCA) is a statistical procedure that is used to perform a comparison of the results of analytical methods applied to a group of samples. In this study, PCA was applied to analyze and identify the honey samples that share similar characteristics from a total number of 45 samples of different honey types from various regions in Romania. The first principal component (PC-1) accounted for $82 \%$ of the variance, while the second principal component (PC-2) accounted for $9 \%$ of the variance; together, the first two principal components accounted for $91 \%$ of the initial variability. The separation of the honey samples according to botanical origin is shown in Figure 1. As seen in Figure 1, there are three ellipses which represent the rape, sunflower and thyme honey, which are not overlapped with other honey samples, except the polyfloral honey. Regarding the mint and raspberry honey, it can be observed that the raspberry honey ellipse is placed in the mint honey ellipse so a clear separation cannot be observed in this sample. Polyfloral honey was not perfectly grouped due to the fact that this honey type has a wide variety of pollen grains.

In Figure 1, the honey types are marked as: RA—rape, T-thyme, $\mathrm{P}$-polyfloral, $\mathrm{S}$ - sunflower, $\mathrm{M}-\mathrm{mint}$, and $\mathrm{R}$-raspberry honey. In Figure 2, the parameters used for the projection are abbreviated as: Pf-Pfund color, $\mathrm{pH}$, Fa—free acidity, EC—electrical conductivity, Mo—moisture, HMF, TPC—total 
polyphenols content, TFC—-total flavonoids content, DPPH, GA—gallic acid, PA—protocatechuic acid, 4-hA-4-Hydroxybenzoic acid, VA-vanillic acid, CA—chlorogenic acid, CafA—caffeic acid, p-CA-p-coumaric acid, RA-rosmarinic acid, My-miricetin, $\mathrm{Qu}$-quercetin, Lu-luteolin, Ka-kaempferol, F-fructose content, G-glucose, S-sucrose, Tu-turanose, Ma-manose, $\mathrm{Tr}$-trehalose, Me—melesitose, Ra—raffinose, GluA—gluconic acid, ForA—formic acid, AcetA—acetic acid, ProA—propionic acid, LacA—lactic acid, ButA—butyric acid, and SucA—succinic acid.

In Figure 2, the parameters which are in the outer ellipse have a greater contribution to variability than the parameters located in the inner ellipse. The rape honey samples were correlated with $\mathrm{L}^{*}$ values, $\mathrm{pH}, \mathrm{c}_{\mathrm{ab}}^{*}, \mathrm{~h}_{\mathrm{ab}}^{*}$, turanose content, manose content and HMF content. The thyme honey samples were correlated with trehalose content and mint honey with caffeic acid, $p$-coumaric acid, vanillic acid, rosmarinic acid and chlorogenic acid content. Regarding the physicochemical parameters, it seems that the moisture content was in opposition to the rest of the parameters.

There was a clear differentiation between Mo variable, the variable groups $\mathrm{Tu}, \mathrm{L}^{*}, \mathrm{Ma}, \mathrm{HMF}, \mathrm{pH}$ and $\mathrm{h}_{\mathrm{ab}}^{*}$ (PC-1 direction) and variable groups TPC and SucA (PC-2 direction). Between variable groups from the PC-1 direction $\left(\mathrm{Tu}, \mathrm{L}^{*}, \mathrm{Ma}, \mathrm{HMF}, \mathrm{pH}, \mathrm{h}_{\mathrm{ab}}{ }^{*}\right.$ and $\left.\mathrm{M}\right)$, there was no correlation with variables TPC and SucA. Between Tu, $\mathrm{L}^{*}, \mathrm{HMF}, \mathrm{pH}$ and $\mathrm{h}^{*} \mathrm{ab}$, and variable Mo, there was negative correlation and the highest fraction of explained variance among these variables was $82 \%$. Furthermore, the small distance between $\mathrm{Tu}, \mathrm{L}^{*}, \mathrm{HMF}, \mathrm{Ma}$ and $\mathrm{h}_{\mathrm{ab}}^{*}$ showed a strong correlation between variables. 
Table 3. Sugars content for different types of Romanian honey. Mean values and standard deviation in brackets.

\begin{tabular}{|c|c|c|c|c|c|c|c|c|c|c|}
\hline \multirow{2}{*}{ Sugars (\%) } & \multicolumn{6}{|c|}{ Origin } & \multirow{2}{*}{ F Value } & \multicolumn{2}{|c|}{ Year } & \multirow{2}{*}{ F Value } \\
\hline & Mint & Polyfloral & Rape & Raspberry & Sunflower & Thyme & & 2017 & 2018 & \\
\hline Fructose & $36.03(2.33)^{\mathrm{a}}$ & $35.15(1.45)^{a}$ & $35.26(1.28)^{a}$ & $36.30(1.43)^{a}$ & $36.74(1.73)^{a}$ & $36.77(3.79)^{\mathrm{a}}$ & $0.8^{\mathrm{ns}}$ & $36.66(2.27)^{a}$ & $35.45(1.51)^{\mathrm{a}}$ & $4.08^{\mathrm{ns}}$ \\
\hline Glucose & $27.87(2.81)$ bc & $24.95(1.27)^{\mathrm{c}}$ & $31.78(2.71)^{\mathrm{a}}$ & $29.00(2.72)^{a b}$ & $28.37(3.97)^{b}$ & $26.86(2.80)$ bc & $4.66^{* *}$ & $28.4(3.96)^{\mathrm{a}}$ & $28.6(3.11)^{a}$ & $0.57^{\mathrm{ns}}$ \\
\hline Sucrose & $0.45(1.09)^{a}$ & $0.73(1.23)^{\mathrm{a}}$ & $0.08(0.20)^{\mathrm{a}}$ & $0.07(0.07)^{\mathrm{a}}$ & $0.35(0.53)^{\mathrm{a}}$ & $0.49(0.78)^{\mathrm{a}}$ & $0.68^{\mathrm{ns}}$ & $0.33(0.74)^{a}$ & $0.34(0.77)^{\mathrm{a}}$ & $0.13^{\mathrm{ns}}$ \\
\hline Turanose & $0.42(0.19)^{\mathrm{a}}$ & $0.2(0.11)^{\mathrm{a}}$ & $0.66(1.24)^{\mathrm{a}}$ & $0.29(0.10)^{\mathrm{a}}$ & $0.38(0.30)^{\mathrm{a}}$ & $0.31(0.26)^{\mathrm{a}}$ & $0.86^{\mathrm{ns}}$ & $0.53(0.88)^{a}$ & $0.31(0.20)^{\mathrm{a}}$ & $1.17^{\mathrm{ns}}$ \\
\hline Maltose & $1.44(0.49)^{\mathrm{a}}$ & $1.79(0.40)^{\mathrm{a}}$ & $1.82(1.52)^{\mathrm{a}}$ & $1.32(0.40)^{\mathrm{a}}$ & $1.62(0.93)^{\mathrm{a}}$ & $1.48(0.84)^{\mathrm{a}}$ & $0.42^{\mathrm{ns}}$ & $1.76(1.12)^{\mathrm{a}}$ & $1.46(0.66)^{\mathrm{a}}$ & $1.86^{\mathrm{ns}}$ \\
\hline Trehalose & $1.45(0.83)^{\mathrm{a}}$ & $1.87(0.58)^{\mathrm{a}}$ & $2.35(3.22)^{a}$ & $1.57(0.58)^{\mathrm{a}}$ & $1.92(1.03)^{\mathrm{a}}$ & $2.07(0.73)^{\mathrm{a}}$ & $0.33^{\text {ns }}$ & $2.1(2.29)^{a}$ & $1.68(0.83)^{a}$ & $0.68^{\mathrm{ns}}$ \\
\hline Melesitose & $1.03(0.31)^{\mathrm{a}}$ & $1.10(0.23)^{\mathrm{a}}$ & $1.08(0.69)^{\mathrm{a}}$ & $0.96(0.28)^{\mathrm{a}}$ & $1.06(0.48)^{\mathrm{a}}$ & $1.34(0.84)^{\mathrm{a}}$ & $0.36^{\mathrm{ns}}$ & $1.21(0.59)^{\mathrm{a}}$ & $0.97(0.35)^{\mathrm{a}}$ & $3.47^{\mathrm{ns}}$ \\
\hline Raffinose & $0.31(0.15)^{\mathrm{ab}}$ & $0.42(0.12)^{\mathrm{a}}$ & $0.21(0.11)^{b}$ & $0.36(0.21)^{\mathrm{ab}}$ & $0.40(0.27)^{\mathrm{ab}}$ & $0.40(0.28)^{\mathrm{ab}}$ & $1.63^{\mathrm{ns}}$ & $0.34(0.21)^{a}$ & $0.33(0.19)^{\mathrm{a}}$ & $0.36^{\mathrm{ns}}$ \\
\hline $\mathrm{F} / \mathrm{G}$ ratio & $1.30(0.14)^{\mathrm{a}}$ & $1.40(0.03)^{\mathrm{a}}$ & $1.11(0.11)^{b}$ & $1.26(0.14)^{\mathrm{ab}}$ & $1.33(0.29)^{\mathrm{a}}$ & $1.38(0.22)^{\mathrm{a}}$ & $3.06 *$ & $1.32(0.24)^{\mathrm{a}}$ & $1.25(0.14)^{\mathrm{a}}$ & $2.68^{\mathrm{ns}}$ \\
\hline
\end{tabular}

ns not significant $(p>0.05){ }^{*} p<0.05, * * p<0.01,{ }^{\text {a-c }}$ different letters in the same row indicate significant differences between samples $(p<0.01)$, according to LSD test with $\alpha=0.05$. F-fructose, G-glucose.

Table 4. Polyphenols content for different types of Romanian honey. Mean values and standard deviation in brackets.

\begin{tabular}{|c|c|c|c|c|c|c|c|c|c|c|}
\hline \multirow{2}{*}{$\begin{array}{l}\text { Polyphenols } \\
\left(\mathrm{mg} \cdot 100 \mathrm{~g}^{-1}\right)\end{array}$} & \multicolumn{6}{|c|}{ Origin } & \multirow{2}{*}{ F Value } & \multicolumn{2}{|c|}{ Year } & \multirow{2}{*}{ F Value } \\
\hline & Mint & Polyfloral & Rape & Raspberry & Sunflower & Thyme & & 2017 & 2018 & \\
\hline Gallic acid & $1.55(1.71)^{\mathrm{a}}$ & $1.03(0.86)^{\mathrm{a}}$ & $0.65(0.27)^{a}$ & $0.95(0.45)^{\mathrm{a}}$ & $0.83(0.46)^{a}$ & $0.57(0.24)^{\mathrm{a}}$ & $1.24^{\mathrm{ns}}$ & $1.00(1.31)^{a}$ & $0.94(0.50)^{\mathrm{a}}$ & $0.14^{\mathrm{ns}}$ \\
\hline Protocatechuic acid & $2.04(2.52)^{a b}$ & $0.71(1.20) \mathrm{bc}$ & $0.44(0.50)^{\mathrm{c}}$ & $2.57(1.47)^{\mathrm{a}}$ & $1.37(0.41)^{\mathrm{abc}}$ & $1.77(1.05)^{a b c}$ & $2.61 *$ & $1.21(1.26)^{a}$ & $1.58(1.77)^{a}$ & $0.69^{\mathrm{ns}}$ \\
\hline 4-Hydroxybenzoic acid & $1.20(1.03)^{a b}$ & $0.52(0.53)^{b}$ & $0.41(0.21)^{b}$ & $2.33(3.09)^{\mathrm{a}}$ & $1.15(0.9)^{a b}$ & $0.83(0.77)^{\mathrm{ab}}$ & $1.70^{\mathrm{ns}}$ & $0.87(0.82)^{a}$ & $1.18(1.70)^{\mathrm{a}}$ & $0.96^{\mathrm{ns}}$ \\
\hline Vanillic acid & $3.03(3.05)^{a}$ & $1.24(2.49)^{a b}$ & $0.17(0.46)^{b}$ & $1.83(3.10)^{a b}$ & $2.35(2.69)^{a b}$ & $1.62(2.72)^{a b}$ & $1.05^{\mathrm{ns}}$ & $1.56(2.99)^{a}$ & $1.87(2.24)^{\mathrm{a}}$ & $0.04^{\mathrm{ns}}$ \\
\hline Chlorogenic acid & $1.48(2.56)^{\mathrm{a}}$ & $1.16(1.94)^{\mathrm{a}}$ & $0.004(0.01)^{\mathrm{a}}$ & $0.45(0.73)^{\mathrm{a}}$ & $0.36(0.67)^{\mathrm{a}}$ & $1.41(2.83)^{\mathrm{a}}$ & $0.93^{\mathrm{ns}}$ & $0.31(1.26)^{a}$ & $1.08(1.90)^{\mathrm{a}}$ & $1.28^{\mathrm{ns}}$ \\
\hline Caffeic acid & $0.23(0.24)^{a}$ & $1.20(2.72)^{\mathrm{a}}$ & $0.18(0.06)^{a}$ & $0.38(0.49)^{\mathrm{a}}$ & $0.30(0.32)^{a}$ & $0.22(0.30)^{a}$ & $0.70^{\mathrm{ns}}$ & $0.22(0.25)^{a}$ & $0.51(1.33)^{a}$ & $0.85^{\mathrm{ns}}$ \\
\hline$P$-coumaric acid & $0.61(0.53)^{\mathrm{a}}$ & $0.70(0.68)^{\mathrm{a}}$ & $0.46(0.32)^{\mathrm{a}}$ & $0.74(0.85)^{\mathrm{a}}$ & $0.80(0.41)^{\mathrm{a}}$ & $1.06(1.07)^{\mathrm{a}}$ & $0.49^{\mathrm{ns}}$ & $0.60(0.57)^{\mathrm{a}}$ & $0.75(0.61)^{\mathrm{a}}$ & $0.55^{\mathrm{ns}}$ \\
\hline Rosmarinic acid & $0^{\mathrm{a}}$ & $0^{\mathrm{a}}$ & $0^{\mathrm{a}}$ & $0.03(0.09)^{a}$ & $0^{\mathrm{a}}$ & $0^{\mathrm{a}}$ & $1.07^{\mathrm{ns}}$ & $0.01(0.05)^{a}$ & $0^{a}$ & $0.44^{\mathrm{ns}}$ \\
\hline Quercetin & $0.30(0.41)^{\mathrm{a}}$ & $0.99(2.28)^{\mathrm{a}}$ & $0^{\mathrm{a}}$ & $0^{\mathrm{a}}$ & $0.19(0.30)^{\mathrm{a}}$ & $0^{\mathrm{a}}$ & $1^{\text {ns }}$ & $0^{\mathrm{a}}$ & $0.43(1.13)^{a}$ & $1.85^{\mathrm{ns}}$ \\
\hline Luteolin & 0 & 0 & 0 & 0 & 0 & 0 & - & 0 & 0 & - \\
\hline Kaempferol & 0 & $0.38(0.94)^{\mathrm{a}}$ & 0 & 0 & 0 & 0 & $1.09^{\mathrm{ns}}$ & 0 & $0.09(0.46)^{a}$ & $0.51^{\mathrm{ns}}$ \\
\hline
\end{tabular}


Table 5. Organic acids content for different types of Romanian honey. Mean values and standard deviation in brackets.

\begin{tabular}{|c|c|c|c|c|c|c|c|c|c|c|}
\hline \multirow{2}{*}{$\begin{array}{l}\text { Organic Acids } \\
\quad\left(\mathrm{g} \cdot \mathrm{kg}^{-1}\right)\end{array}$} & \multicolumn{6}{|c|}{ Origin } & \multirow{2}{*}{ F Value } & \multicolumn{2}{|c|}{ Year } & \multirow{2}{*}{ F Value } \\
\hline & Mint & Polyfloral & Rape & Raspberry & Sunflower & Thyme & & 2017 & 2018 & \\
\hline Gluconic acid & $4.46(1.53)^{\mathrm{ab}}$ & $4.21(0.48)^{a b}$ & $3.59(1.12)^{b}$ & $4.83(0.34)^{a}$ & $4.76(0.55)^{\mathrm{a}}$ & $4.50(0.49)^{\mathrm{ab}}$ & $1.60^{\mathrm{ns}}$ & $4.11(1.40)^{\mathrm{a}}$ & $4.53(0.53)^{a}$ & $1.57^{\mathrm{ns}}$ \\
\hline Formic acid & $0.37(0.43)^{a b}$ & $0.18(0.09)^{b}$ & $0.21(0.17)^{b}$ & $0.28(0.27)^{a b}$ & $0.53(0.36)^{a b}$ & $0.77(1.01)^{\mathrm{a}}$ & $1.60^{\mathrm{ns}}$ & $0.30(0.31)^{\mathrm{a}}$ & $0.42(0.49)^{\mathrm{a}}$ & $1.15^{\mathrm{ns}}$ \\
\hline Acetic acid & $0.77(0.30)^{\mathrm{a}}$ & $0.39(0.22)^{b c}$ & $0.18(0.05)^{\mathrm{c}}$ & $0.58(0.20)^{\mathrm{ab}}$ & $0.4(0.26)^{b c}$ & $0.3(0.08)^{b c}$ & $6.99^{* * *}$ & $0.41(0.25)^{\mathrm{a}}$ & $0.47(0.33)^{a}$ & $0.75^{\mathrm{ns}}$ \\
\hline Propionic acid & $2.67(1.52)^{\mathrm{a}}$ & $0.72(0.26)^{b}$ & $0.62(0.42)^{b}$ & $0.86(0.49)^{b}$ & $0.79(0.28)^{b}$ & $2.36(0.29)^{a}$ & $11.36^{* * *}$ & $1.48(1.09)^{\mathrm{a}}$ & $1.17(1.20)^{\mathrm{a}}$ & $1.11^{\mathrm{ns}}$ \\
\hline Lactic acid & $0.18(0.28)^{b}$ & $0.12(0.22)^{b}$ & $0.14(0.26)^{b}$ & $0.09(0.07)^{b}$ & $0.14(0.20)^{b}$ & $0.59(0.52)^{\mathrm{a}}$ & $1.66^{\mathrm{ns}}$ & $0.18(0.26)^{a}$ & $0.17(0.30)^{\mathrm{a}}$ & $0^{\mathrm{ns}}$ \\
\hline Butyric acid & $0.51(0.42)^{\mathrm{a}}$ & $0.87(1.61)^{\mathrm{a}}$ & $0.07(0.11)^{\mathrm{a}}$ & $0.11(0.16)^{\mathrm{a}}$ & $0.32(0.38)^{a}$ & $0.23(0.20)^{\mathrm{a}}$ & $1.25^{\mathrm{ns}}$ & $0.28(0.33)^{a}$ & $0.39(0.84)^{\mathrm{a}}$ & $0.18^{\text {ns }}$ \\
\hline Succinic acid & $0.13(0.12)^{\mathrm{a}}$ & $0.1(0.19)^{a}$ & $0.09(0.14)^{a}$ & $0.05(0.11)^{\mathrm{a}}$ & $0.11(0.09)^{a}$ & $0.08(0.07)^{a}$ & $0.24^{\mathrm{ns}}$ & $0.09(0.13)^{\mathrm{a}}$ & $0.10(0.12)^{a}$ & $0.01^{\mathrm{ns}}$ \\
\hline
\end{tabular}

${ }^{n s}$ not significant $(p>0.05),{ }^{* * *} p<0.001{ }^{\text {a-c }}$ different letters in the same row indicate significant differences between samples $(p<0.05)$, according to the LSD test with $\alpha=0.05$. 


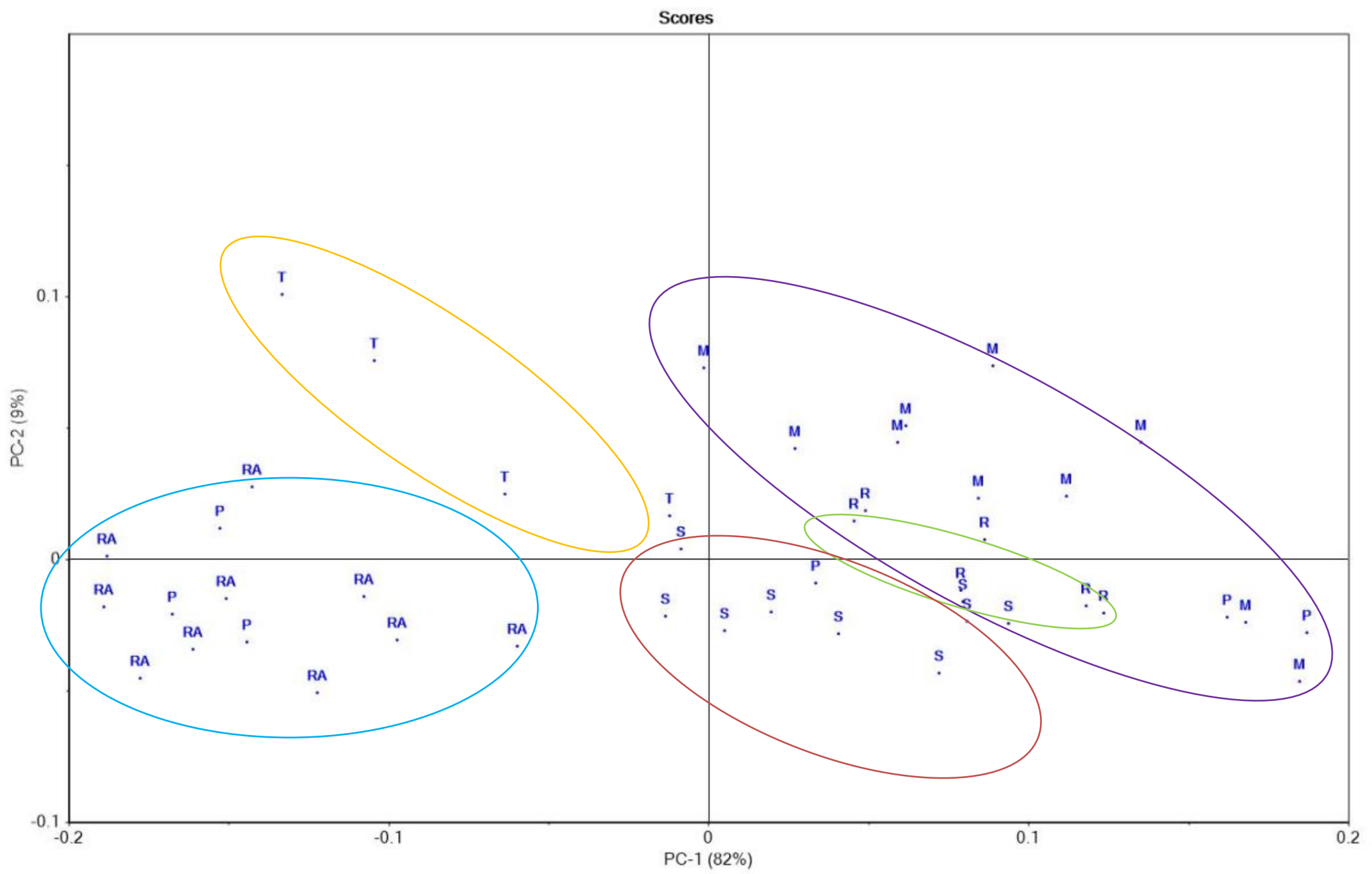

Figure 1. Principal component analysis—scores: RA—rape, T—-thyme, P—polyfloral, S—sunflower, M-mint, and R—raspberry honey. Blue ellipse—rape honey group, yellow ellipse—thyme honey group, red ellipse—sunflower honey group, green ellipse—raspberry honey group, and purple ellipse—mint honey group. 


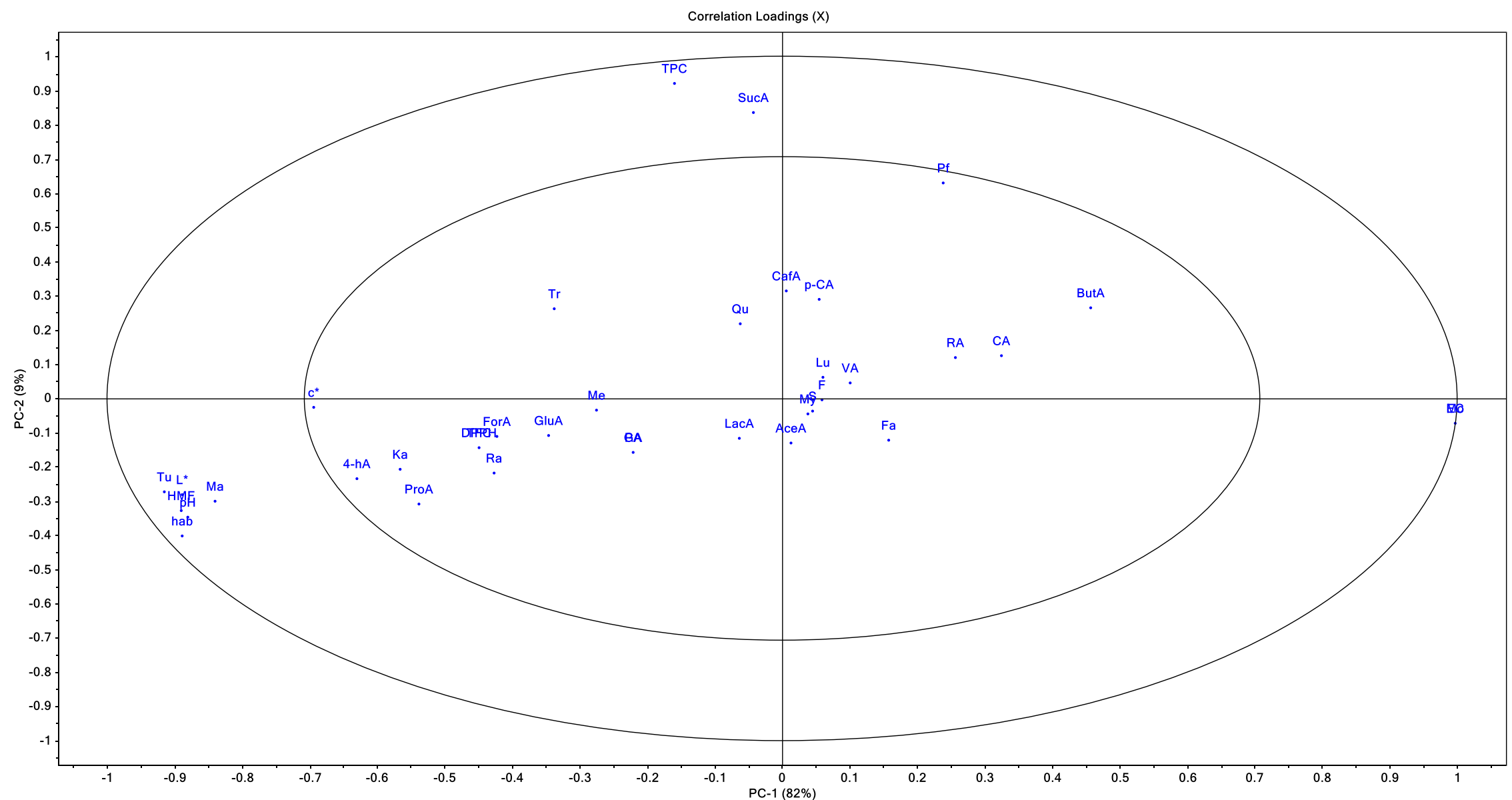

Figure 2. Principal component analysis-loadings: $\mathrm{L}^{*}, \mathrm{~h}_{\mathrm{ab}}^{*}, \mathrm{c}_{\mathrm{ab}}^{*}$, Pf-Pfund color, $\mathrm{pH}, \mathrm{Fa}-$ free acidity, EC-electrical conductivity, Mo-moisture, HMF, TPC—-total polyphenols content, TFC—-total flavonoids content, DPPH, GA—gallic acid, PA—protocatechuic acid, 4-hA—4-Hydroxybenzoic acid, VA—vanillic acid, CA—chlorogenic acid, CafA—caffeic acid, p-CA-p-coumaric acid, RA—rosmarinic acid, My-miricetin, Qu—quercetin, Lu—luteolin, Ka—kaempferol, F-fructose content, G-glucose, S-sucrose, Tu—turanose, Ma-manose, Tr-trehalose, Me-melesitose, Ra—raffinose, GluA—gluconic acid, ForA-formic acid, AcetA-acetic acid, ProA—propionic acid, LacA—lactic acid, ButA—butyric acid, and SucA—succinic acid. 


\section{Conclusions}

The physicochemical parameters of raspberry, mint, sunflower, thyme, rape and polyfloral honey samples from different regions in Romania were analyzed in order to examine their usefulness in the classification of honey according to botanical origin. All honey samples had $\mathrm{pH}$ and free acidity values in the limits permitted by quality standards, which confirm the freshness of all honey samples. With the exception of three samples (two samples of mint honey and one sample of thyme honey) that had HMF content above the allowed limit, all the samples that were analyzed in this study met the quality requirements for honey. For most of the physicochemical parameters (color parameters, electrical conductivity, HMF content, $\mathrm{DPPH}$, free acidity and $\mathrm{pH}$ ) the differences between the measured levels were determined by the botanical origin of honey. The sugar composition, individual phenolic compounds and organic acids composition of honey varied to some extent between samples, however, these parameters were not influenced by the botanical origin of honey. As a consequence, no compound that can be used as a chemical marker was identified. PCA analysis was successful in the rape, sunflower and thyme honey samples while the mint and raspberry honey have not been clearly separated, but for a better classification of unknown honey it is necessary to increase the number of samples analyzed.

Author Contributions: Conceptualization, D.P.; formal analysis, D.P. and F.D.; funding acquisition, M.O.; investigation, D.P.; methodology, D.P., F.D. and M.O.; project administration, M.O.; software, F.D.; supervision, M.O.; validation, D.P.; writing - original draft, D.P.; writing—review and editing, F.D. and M.O. All authors have read and agreed to the published version of the manuscript.

Funding: This work was supported by contract no. 18PFE/16.10.2018 funded by the Ministry of Research and Innovation within Program 1-Development of national research and development system, Subprogram 1.2-Institutional Performance -RDI excellence funding projects.

Conflicts of Interest: The authors declare no conflict of interest.

\section{References}

1. Jones, R. Prologue: Honey and healing through the ages. J. ApiProduct ApiMedical Sci. 2009, 1,1-5. [CrossRef]

2. Codex Alimentarius Commission. Codex Alimentarius Commission Standards, Codex Stan 12-1981; Codex Alimentarius Commission: Rome, Italy, 2001.

3. Communities. Directive 2001/77/Ec. Off. J. Eur. Communities 2001, 6, 33-40.

4. Oroian, M.; Amariei, S.; Escriche, I.; Leahu, A.; Damian, C.; Gutt, G. Chemical composition and temperature influence on the rheological behaviour of honeys. Int. J. Food Prop. 2014, 17, 2228-2240. [CrossRef]

5. Terrab, A.; Recamales, A.F.; Hernanz, D.; Heredia, F.J. Characterisation of Spanish thyme honeys by their physicochemical characteristics and mineral contents. Food Chem. 2004, 88, 537-542. [CrossRef]

6. El Sohaimy, S.A.; Masry, S.H.D.; Shehata, M.G. Physicochemical characteristics of honey from different origins. Ann. Agric. Sci. 2015, 60, 279-287. [CrossRef]

7. Anjos, O.; Campos, M.G.; Ruiz, P.C.; Antunes, P. Application of FTIR-ATR spectroscopy to the quantification of sugar in honey. Food Chem. 2015, 169, 218-223. [CrossRef]

8. Bogdanov, S.; Martin, P. Honey authenticity. Mitteilungen Aus Leb. Und Hyg. 2002, 93, 232-254.

9. Kasprzyk, I.; Depciuch, J.; Grabek-Lejko, D.; Parlinska-Wojtan, M. FTIR-ATR spectroscopy of pollen and honey as a tool for unifloral honey authentication. The case study of rape honey. Food Control. 2018, 84, 33-40. [CrossRef]

10. Anklam, E. A review of the analytical methods to determine the geographical and botanical origin of honey. Food Chem. 1998, 63, 549-562. [CrossRef]

11. Da Silva, P.M.; Gauche, C.; Gonzaga, L.V.; Costa, A.C.O.; Fett, R. Honey: Chemical composition, stability and authenticity. Food Chem. 2016, 196, 309-323. [CrossRef]

12. Baroni, M.V.; Podio, N.S.; Badini, R.G.; Inga, M.; Ostera, H.A.; Cagnoni, M.; Gautier, E.A.; García, P.P.; Hoogewerff, J.; Wunderlin, D.A. Linking soil, water, and honey composition to assess the geographical origin of Argentinean honey by multielemental and isotopic analyses. J. Agric. Food Chem. 2015, 63, 4638-4645. [CrossRef] [PubMed] 
13. Kaškoniene, V.; Venskutonis, P.R. Floral markers in honey of various botanical and geographic origins: A review. Compr. Rev. Food Sci. Food Saf. 2010, 9, 620-634. [CrossRef]

14. Escriche, I.; Kadar, M.; Domenech, E.; Gil-Sánchez, L. A potentiometric electronic tongue for the discrimination of honey according to the botanical origin. Comparison with traditional methodologies: Physicochemical parameters and volatile profile. J. Food Eng. 2012, 109, 449-456. [CrossRef]

15. Bogdanov, S.; Jurendic, T.; Sieber, R.; Gallmann, P. Honey for nutrition and health: A review. J. Am. Coll. Nutr. 2008, 27, 677-689. [CrossRef] [PubMed]

16. Siddiqui, A.J.; Musharraf, S.G.; Choudhary, M.I.; Rahman, A.U. Application of analytical methods in authentication and adulteration of honey. Food Chem. 2017, 217, 687-698. [CrossRef] [PubMed]

17. Karabagias, I.K.; Badeka, A.; Kontakos, S.; Karabournioti, S.; Kontominas, M.G. Characterization and classification of Thymus capitatus (L.) honey according to geographical origin based on volatile compounds, physicochemical parameters and chemometrics. Food Res. Int. 2014, 55, 363-372. [CrossRef]

18. Consonni, R.; Cagliani, L.R. Recent developments in honey characterization. RSC Adv. 2015, 5, 59696-59714. [CrossRef]

19. Oroian, M.; Paduret, S.; Ropciuc, S. Honey adulteration detection: voltammetric e-tongue versus official methods for physicochemical parameter determination. J. Sci. Food Agric. 2018, 98, 4304-4311. [CrossRef]

20. Escriche, I.; Sobrino-Gregorio, L.; Conchado, A.; Juan-Borrás, M. Volatile profile in the accurate labelling of monofloral honey. The case of lavender and thyme honey. Food Chem. 2017, 226, 61-68. [CrossRef]

21. Hawkins, J.; de Vere, N.; Griffith, A.; Ford, C.R.; Allainguillaume, J.; Hegarty, M.J.; Baillie, L.; Adams-Groom, B. Using DNA metabarcoding to identify the floral composition of honey: A new tool for investigating honey bee foraging preferences. PLOS ONE 2015, 10, e0134735. [CrossRef]

22. Soares, S.; Grazina, L.; Mafra, I.; Costa, J.; Pinto, M.A.; Oliveira, M.B.P.P.; Amaral, J.S. Towards honey authentication: Differentiation of Apis mellifera subspecies in European honeys based on mitochondrial DNA markers. Food Chem. 2019, 283, 294-301. [CrossRef] [PubMed]

23. Svečnjak, L.; Biliškov, N.; Bubalo, D.; Barišić, D. Application of infrared spectroscopy in honey analysis. Agric. Conspec. Sci. 2011, 76, 191-195.

24. Elamine, Y.; Inácio, P.M.C.; Lyoussi, B.; Anjos, O.; Estevinho, L.M.; Miguel, M.d.; Gomes, H.L. Insight into the sensing mechanism of an impedance based electronic tongue for honey botanic origin discrimination. Sens. Actuators B Chem. 2019, 285, 24-33. [CrossRef]

25. Sousa, M.E.B.C.; Dias, L.G.; Veloso, A.C.A.; Estevinho, L.; Peres, A.M.; Machado, A.A.S.C. Practical procedure for discriminating monofloral honey with a broad pollen profile variability using an electronic tongue. Talanta 2014, 128, 284-292. [CrossRef]

26. Bertram, H.C.; Kristensen, N.B.; Malmendal, A.; Nielsen, N.C.; Bro, R.; Andersen, H.J.; Harmon, D.L. A metabolomic investigation of splanchnic metabolism using 1H NMR spectroscopy of bovine blood plasma. Anal. Chim. Acta. 2005, 536, 1-6. [CrossRef]

27. Spiteri, M.; Jamin, E.; Thomas, F.; Rebours, A.; Lees, M.; Rogers, K.M.; Rutledge, D.N. Fast and global authenticity screening of honey using 1H-NMR profiling. Food Chem. 2015, 189, 60-66. [CrossRef] [PubMed]

28. Louveaux, J.; Maurizio, A.; Vorwohl, G. Methods of melissopalynology. Bee World 1978, 59, $139-157$. [CrossRef]

29. Bogdanov, S.; Lüllmann, C.; Martin, P.; von der Ohe, W.; Russmann, H.; Vorwohl, G.; Oddo, L.P.; Sabatini, A.-G.; Marcazzan, G.L.; Piro, R.; et al. Honey quality and international regulatory standards: Review by the international honey commission. Bee World 1999, 80, 61-69. [CrossRef]

30. Biesaga, M.; Pyrzyńska, K. Stability of bioactive polyphenols from honey during different extraction methods. Food Chem. 2013, 136, 46-54. [CrossRef]

31. Brand-Williams, W.; Cuvelier, M.E.; Berset, C. Use of a free radical method to evaluate antioxidant activity. LWT-Food Sci. Technol. 1995, 28, 25-30. [CrossRef]

32. Palacios, I.; Lozano, M.; Moro, C.; D’Arrigo, M.; Rostagno, M.A.; Martínez, J.A.; García-Lafuente, A.; Guillamón, E.; Villares, A. Antioxidant properties of phenolic compounds occurring in edible mushrooms. Food Chem. 2011, 128, 674-678. [CrossRef]

33. Özcelik, S.; Kuley, E.; Özogul, F. Formation of lactic, acetic, succinic, propionic, formic and butyric acid by lactic acid bacteria. LWT-Food Sci. Technol. 2016, 73, 536-542. [CrossRef]

34. Pires, J.; Estevinho, M.L.; Feás, X.; Cantalapiedra, J.; Iglesias, A. Pollen spectrum and physico-chemical attributes of heather (Erica sp.) honeys of north Portugal. J. Sci. Food Agric. 2009, 89, 1862-1870. [CrossRef] 
35. Sakač, M.B.; Jovanov, P.T.; Marić, A.Z.; Pezo, L.L.; Kevrešan, Ž.S.; Novaković, A.R.; Nedeljković, N.M. Physicochemical properties and mineral content of honey samples from Vojvodina (Republic of Serbia). Food Chem. 2019, 276, 15-21. [CrossRef] [PubMed]

36. Boussaid, A.; Chouaibi, M.; Rezig, L.; Hellal, R.; Donsì, F.; Ferrari, G.; Hamdi, S. Physicochemical and bioactive properties of six honey samples from various floral origins from Tunisia. Arab. J. Chem. 2018, 11, 265-274. [CrossRef]

37. Al, M.L.; Daniel, D.; Moise, A.; Bobis, O.; Laslo, L.; Bogdanov, S. Physico-chemical and bioactive properties of different floral origin honeys from Romania. Food Chem. 2009, 112, 863-867. [CrossRef]

38. Küçük, M.; Kolayli, S.; Karaoğlu, Ş.; Ulusoy, E.; Baltaci, C.; Candan, F. Biological activities and chemical composition of three honeys of different types from Anatolia. Food Chem. 2007, 100, 526-534. [CrossRef]

39. Escuredo, O.; Míguez, M.; Fernández-González, M.; Seijo, M.C. Nutritional value and antioxidant activity of honeys produced in a European Atlantic area. Food Chem. 2013, 138, 851-856. [CrossRef]

40. Halliwell, B.; Gutteridge, J.M.C. Cellular responses to oxidative stress: Adaptation, damage, repair, senescence and death. In Free Radicals in Biology and Medicine; Halliwell, B., Gutteridge, J.M.C., Eds.; Oxford University Press: Oxford, UK, 2007.

41. Council, E.U. Council Directive 2001/110/EC of 20 December 2001 relating to honey. Communities 2002, 10, 47-52.

42. Lazarević, K.B.; Andrić, F.; Trifković, J.; Tešić, Ž.; Milojković-Opsenica, D. Characterisation of Serbian unifloral honeys according to their physicochemical parameters. Food Chem. 2012, 132, 2060-2064. [CrossRef]

43. Šarić, G.; Matković, D.; Hruškar, M.; Vahčić, N. Characterisation and classification of Croatian honey by physicochemical parameters. Food Technol. Biotechnol. 2008, 46, 355-367.

44. Oroian, M.; Ropciuc, S. Honey authentication based on physicochemical parameters and phenolic compounds. Comput. Electron. Agric. 2017, 138, 148-156. [CrossRef]

45. Önür, İ.; Misra, N.N.; Barba, F.J.; Putnik, P.; Lorenzo, J.M.; Gökmen, V.; Alpas, H. Effects of ultrasound and high pressure on physicochemical properties and HMF formation in Turkish honey types. J. Food Eng. 2018, 219, 129-136. [CrossRef]

46. Rodríguez, I.; Cámara-Martos, F.; Flores, J.M.; Serrano, S. Spanish avocado (Persea americana Mill.) honey: Authentication based on its composition criteria, mineral content and sensory attributes. LWT 2019, 111, 561-572. [CrossRef]

47. Nascimento, K.S.D.; Sattler, J.A.G.; Macedo, L.F.L.; González, C.V.S.; de Melo, I.L.P.; Araújo, E.d.; Granato, D.; Sattler, A.; de Almeida-Muradian, L.B. Phenolic compounds, antioxidant capacity and physicochemical properties of Brazilian Apis mellifera honeys. LWT-Food Sci. Technol. 2018, 91, 85-94. [CrossRef]

48. González-Miret, M.L.; Terrab, A.; Hernanz, D.; Fernández-Recamales, M.Á.; Heredia, F.J. Multivariate correlation between color and mineral composition of honeys and by their botanical origin. J. Agric. Food Chem. 2005, 53, 2574-2580. [CrossRef]

49. Solayman, M.; Islam, M.A.; Paul, S.; Ali, Y.; Khalil, M.I.; Alam, N.; Gan, S.H. Physicochemical properties, minerals, trace elements, and heavy metals in honey of different origins: A comprehensive review. Compr. Rev. Food Sci. Food Saf. 2016, 15, 219-233. [CrossRef]

50. Manzanares, A.B.; García, Z.H.; Galdón, B.R.; Rodríguez, E.R.; Romero, C.D. Physicochemical characteristics of minor monofloral honeys from Tenerife, Spain. LWT-Food Sci. Technol. 2014, 55, 572-578. [CrossRef]

51. Saxena, S.; Gautam, S.; Sharma, A. Physical, biochemical and antioxidant properties of some Indian honeys. Food Chem. 2010, 118, 391-397. [CrossRef]

52. Oroian, M.; Amariei, S.; Leahu, A.; Gutt, G. Multi-element composition of honey as a suitable tool for its authenticity analysis. Pol. J. Food Nutr. Sci. 2015, 65, 93-100. [CrossRef]

53. Oroian, M.; Ropciuc, S.; Paduret, S.; Todosi, E. Rheological analysis of honeydew honey adulterated with glucose, fructose, inverted sugar, hydrolysed inulin syrup and malt wort. LWT 2018, 95, 1-8. [CrossRef]

54. Oroian, M.; Ropciuc, S.; Paduret, S. Honey adulteration detection using raman spectroscopy. Food Anal. Methods 2017, 11, 959-968. [CrossRef]

55. Kaškoniene, V.; Venskutonis, P.R.; Čeksteryte, V. Carbohydrate composition and electrical conductivity of different origin honeys from Lithuania. LWT-Food Sci. Technol. 2010, 43, 801-807. [CrossRef]

56. Oroian, M.; Amariei, S.; Rosu, A.; Gutt, G. Classification of unifloral honeys using multivariate analysis. J. Essent. Oil Res. 2015, 27, 533-544. [CrossRef] 
57. Piazza, M.G.; Oddo, L.P. Bibliographical review of the main European unifloral honeys. Apidologie 2004, 35, S94-S111. [CrossRef]

58. Devillers, J.; Morlot, M.; Pham-Delègue, M.H.; Doré, J.C. Classification of monofloral honeys based on their quality control data. Food Chem. 2004, 86, 305-312. [CrossRef]

59. Terrab, A.; González, A.G.; Díez, M.J.; Heredia, F.J. Characterisation of Moroccan unifloral honeys using multivariate analysis. Eur. Food Res. Technol. 2003, 218, 88-95. [CrossRef]

60. Yücel, Y.; Sultanoğlu, P. Characterization of Hatay honeys according to their multi-element analysis using ICP-OES combined with chemometrics. Food Chem. 2013, 140, 231-237. [CrossRef]

61. Schramm, D.D.; Karim, M.; Schrader, H.R.; Holt, R.R.; Cardetti, M.; Keen, C.L. Honey with high levels of antioxidants can provide protection to healthy human subjects. J. Agric. Food Chem. 2003, 51, 1732-1735. [CrossRef]

62. Sergiel, I.; Pohl, P.; Biesaga, M. Characterisation of honeys according to their content of phenolic compounds using high performance liquid chromatography/tandem mass spectrometry. Food Chem. 2014, 145, 404-408. [CrossRef]

63. Gheldof, N.; Engeseth, N.J. Antioxidant capacity of honeys from various floral sources based on the determination of oxygen radical absorbance capacity and inhibition of in vitro lipoprotein oxidation in human serum samples. J. Agric. Food Chem. 2002, 50, 3050-3055. [CrossRef]

64. Chua, L.S.; Rahaman, N.L.A.; Adnan, N.A.; Tan, T.T.E. Antioxidant activity of three honey samples in relation with their biochemical components. J. Anal. Methods Chem. 2013, 2013, 313798. [CrossRef]

65. Hamdy, A.A.; Ismail, H.M.; Al-Ahwal, A.E.-M.A.; Gomaa, N.F. Determination of flavonoid and phenolic Acid contents of clover, cotton and citrus floral honeys. J. Egypt. Public Health Assoc. 2009, 84, 245-259. [PubMed]

66. Khalil, M.I.; Moniruzzaman, M.; Boukraâ, L.; Benhanifia, M.; Islam, M.A.; Islam, M.N.; Sulaiman, S.A.; Gan, S.H. Physicochemical and antioxidant properties of algerian honey. Molecules 2012, 17, 11199-11215. [CrossRef] [PubMed]

67. Lachman, J.; Orsák, M.; Hejtmánková, A.; Kovářová, E. Evaluation of antioxidant activity and total phenolics of selected Czech honeys. LWT-Food Sci. Technol. 2010, 43, 52-58. [CrossRef]

68. Blasa, M.; Candiracci, M.; Accorsi, A.; Piacentini, M.P.; Albertini, M.C.; Piatti, E. Raw Millefiori honey is packed full of antioxidants. Food Chem. 2006, 97, 217-222. [CrossRef]

69. Salonen, A.; Virjamo, V.; Tammela, P.; Fauch, L.; Julkunen-Tiitto, R. Screening bioactivity and bioactive constituents of Nordic unifloral honeys. Food Chem. 2017, 237, 214-224. [CrossRef] [PubMed]

70. Ruiz-Navajas, Y.; Viuda-Martos, M.; Fernández-López, J.; Zaldivar-Cruz, J.M.; Kuri, V.; Pérez-Álvarez, J.Á. Antioxidant activity of artisanal honey from Tabasco, Mexico. Int. J. Food Prop. 2011, 14, 459-470. [CrossRef]

71. Baltrušaityte, V.; Venskutonis, P.R.; Čeksteryte, V. Radical scavenging activity of different floral origin honey and beebread phenolic extracts. Food Chem. 2007, 101, 502-514. [CrossRef]

72. Leite, J.M.D.; Trugo, L.C.; Costa, L.S.M.; Quinteiro, L.M.C.; Barth, O.M.; Dutra, V.M.L.; de Maria, C.A.B. Determination of oligosaccharides in Brazilian honeys of different botanical origin. Food Chem. 2000, 70, 93-98. [CrossRef]

73. Ouchemoukh, S.; Schweitzer, P.; Bey, M.B.; Djoudad-Kadji, H.; Louaileche, H. HPLC sugar profiles of Algerian honeys. Food Chem. 2010, 121, 561-568. [CrossRef]

74. Venir, E.; Spaziani, M.; Maltini, E. Crystallization in “Tarassaco" Italian honey studied by DSC. Food Chem. 2010, 122, 410-415. [CrossRef]

75. Alvarez-Suarez, J.M.; Tulipani, S.; Díaz, D.; Estevez, Y.; Romandini, S.; Giampieri, F.; Damiani, E.; Astolfi, P.; Bompadre, S.; Battino, M. Antioxidant and antimicrobial capacity of several monofloral Cuban honeys and their correlation with color, polyphenol content and other chemical compounds. Food Chem. Toxicol. 2010, 48, 2490-2499. [CrossRef] [PubMed]

76. Cotte, J.F.; Casabianca, H.; Chardon, S.; Lheritier, J.; Grenier-Loustalot, M.F. Chromatographic analysis of sugars applied to the characterisation of monofloral honey. Anal. Bioanal. Chem. 2004, 380, 698-705. [CrossRef] [PubMed]

77. Kroyer, G.; Hegedus, N. Evaluation of bioactive properties of pollen extracts as functional dietary food supplement. Innov. Food Sci. Emerg. Technol. 2001, 2, 171-174. [CrossRef] 
78. Kečkeš, S.; Gašić, U.; Veličković, T.Ć.; Milojković-Opsenica, D.; Natić, M.; Tešić, Ž. The determination of phenolic profiles of Serbian unifloral honeys using ultra-high-performance liquid chromatography/high resolution accurate mass spectrometry. Food Chem. 2013, 138, 32-40. [CrossRef] [PubMed]

79. Rosa, A.; Tuberoso, C.I.G.; Atzeri, A.; Melis, M.P.; Bifulco, E.; Dess, M.A. Antioxidant profile of strawberry tree honey and its marker homogentisic acid in several models of oxidative stress. Food Chem. 2011, 129, 1045-1053. [CrossRef] [PubMed]

80. Estevinho, L.; Pereira, A.P.; Moreira, L.; Dias, L.G.; Pereira, E. Antioxidant and antimicrobial effects of phenolic compounds extracts of Northeast Portugal honey. Food Chem. Toxicol. 2008, 46, 3774-3779. [CrossRef]

81. Gašić, U.M.; Milojković-Opsenica, D.M.; Tešić, Ž.L. Polyphenols as possible markers of botanical origin of honey. J. AOAC Int. 2017, 100, 852-861. [CrossRef]

82. Mato, I.; Huidobro, J.F.; Simal-Lozano, J.; Sancho, M.T. Rapid determination of nonaromatic organic acids in honey by capillary zone electrophoresis with direct ultraviolet detection. J. Agric. Food Chem. 2006, 54, 1541-1550. [CrossRef]

83. Daniele, G.; Maitre, D.; Casabianca, H. Identification, quantification and carbon stable isotopes determinations of organic acids in monofloral honeys. A powerful tool for botanical and authenticity control. Rapid Commun. Mass Spectrom. 2012, 26, 1993-1998. [CrossRef] [PubMed]

84. Brugnerotto, P.; della Betta, F.; Gonzaga, L.V.; Fett, R.; Costa, A.C.O. A capillary electrophoresis method to determine aliphatic organic acids in bracatinga honeydew honey and floral honey. J. Food Compos. Anal. 2019, 82, 103243. [CrossRef]

85. Suárez-Luque, S.; Mato, I.; Huidobro, J.F.; Simal-Lozano, J.; Sancho, M.T. Rapid determination of minority organic acids in honey by high-performance liquid chromatography. J. Chromatogr. A 2002, 955, 207-214. [CrossRef]

86. Barra, M.P.G.; Ponce-Díaz, M.C.; Venegas-Gallegos, C. Volatile compounds in honey produced in the central valley of Nuble Province, Chile. Chil. J. Agric. Res. 2010, 70, 75-84. [CrossRef]

(C) 2020 by the authors. Licensee MDPI, Basel, Switzerland. This article is an open access article distributed under the terms and conditions of the Creative Commons Attribution (CC BY) license (http://creativecommons.org/licenses/by/4.0/). 